\title{
A melt-focusing zone in the lithospheric mantle preserved in the Santa Elena Ophiolite, Costa Rica
}

Pilar Madrigal ${ }^{1}$, Esteban Gazel ${ }^{1}$, Percy Denyer ${ }^{2}$, Ian Smith ${ }^{3}$, Brian Jicha ${ }^{4}$, Kennet E. Flores ${ }^{5}$, Drew Coleman ${ }^{6}$, Jonathan Snow ${ }^{7}$

${ }^{1}$ Department of Geosciences, Virginia Tech, Blacksburg, Virginia, USA; ${ }^{2}$ Escuela Centroamericana de Geologia, Universidad de Costa Rica, San Jose, Costa Rica; ${ }^{3}$ School of Environment, University of Auckland, Auckland, Australia; ${ }^{4}$ Department of Geoscience, University of Wisconsin-Madison, Madison, Wisconsin, USA; ${ }^{5}$ Department of Earth and Environmental Sciences, Brooklyn College, Brooklyn, New York, USA; ${ }^{6}$ Department of Geological Sciences, University of North Carolina Chapel Hill, Chapel Hill, North Carolina, USA; ${ }^{7}$ Department of Earth and Atmospheric Sciences, University of Houston, Houston, Texas, USA.

Correspondence to:

E. Gazel, Department of Geosciences

4044 Derring Hall (0420), Blacksburg, Virginia 24061

+1 540/231-2296 Fax: +1 540/231-3386

egazel@vt.edu

Submitted to Lithos with revisions

Word count (Abstract 268, Text 7789)

\section{Index terms and Keywords}

Santa Elena Ophiolite, melt-focusing zone, lithospheric mantle, oceanic core complex. 


\section{Abstract}

The Santa Elena Ophiolite in Costa Rica is comprised of a well-preserved fragment of the lithospheric mantle that formed along a paleo-spreading center. Within its exposed architecture, this ophiolite records a deep section of the melt transport system of a slow/ultra-slow spreading environment, featuring a well-developed melt-focusing system of coalescent diabase dikes that intrude the peridotite in a sub-vertical and sub-parallel arrangement. Here we present an integrated analysis of new structural data, ${ }^{40} \mathrm{Ar} /{ }^{39} \mathrm{Ar}$ geochronology, major and trace element geochemistry and radiogenic isotopes data from the diabase dikes in order to elucidate the tectonic setting of the Santa Elena ophiolite. The dikes are basaltic and tholeiitic in composition. Petrological models of fractional crystallization suggest deep pressures of crystallization of $>0.4 \mathrm{GPa}$ for most of the samples, which is in good agreement with similar calculations from slow/ultra-slow spreading ridges and require a relatively hydrated ( 0.5 wt\% $\left.\mathrm{H}_{2} \mathrm{O}\right)$ MORB-like source composition. The diabase dikes share geochemical and isotope signatures with both slow/ultra-slow spreading ridges and back-arc basins and indicate mixing of a DMM source and an enriched mantle end-member like EMII. The ${ }^{40} \mathrm{Ar} /{ }^{39} \mathrm{Ar}$ geochronology yields an age of $131 \mathrm{Ma}$ for a previous pegmatitic gabbroic magmatic event that intruded the peridotite when it was hot and plastic and an age of $121 \mathrm{Ma}$ for the diabase intrusions, constraining the cooling from near asthenospheric conditions to lithospheric mantle conditions to $10 \mathrm{Ma}$. Our findings suggest a complex interplay between oceanic basin and back-arc extension environments during the Santa Elena Ophiolite formation. We propose an alternative hypothesis for the origin of Santa Elena as an obducted fragment of an oceanic core complex (OCC). 


\section{Introduction}

To understand the evolution of our planet, it is fundamental to constrain melt generation and transport processes that occur in the mantle. In an extensional environment, when the upper mantle crosses its solidus through decompression, melting initiates as an inter-granular network of melt (Karato and Jung, 1998; Kelemen et al., 2000; Faul, 2001; Dasgupta and Hirschmann, 2006). Then, physical and chemical changes during reactive melt transport allow segregation of the partial melts increasing the porosity of the upper mantle host (Kelemen et al., 1997; Kelemen et al., 2000; Spiegelman et al., 2001). At extensional environments like mid-ocean ridges (Fig. 1), basaltic melts separate from the peridotite residue and react with the lithospheric mantle as they rise buoyantly through this network of melt (Kelemen et al., 2000; Bouilhol et al., 2011). After these ascending melts coalesce and evolve beneath the ridge axis they erupt to produce new oceanic crust (O'Hara, 1985).

Because it is difficult to reach deep segments of extensional regimes (i.e. mid-ocean ridges, forearc basins, back-arc basins) we rely on more accessible geologic features as analogous to these environments, such as ophiolites. Ophiolites consist of ultramafic and mafic mantle lithologies that formed along spreading centers and get subsequently obducted or exposed onto continents by tectonic

processes. Conceptually, ophiolite assemblages are composed from bottom to top, of peridotite (including Iherzolite, harzburgite and dunite) variably altered to serpentinite; gabbro and diabase intrusions; and extrusive sequences of pillow lavas and massive flows that are typically overlain by deepsea sediments (Coleman, 1971; Dewey and Bird, 1971; Dewey, 1976; Steinmann et al., 2003; Dilek and Furnes, 2011; Dilek and Furnes, 2014). Although such lithological associations have commonly been attributed to mid-ocean ridge or back-arc origin, other interpretations for ophiolite origins also exist, 
such as supra-subduction zone (SSZ) ophiolites, plume-related ophiolites and continental margin ophiolites (see Dewey and Casey, 2011; Dilek and Furnes, 2014 and references therein).

Based on geochemical affinities and order of mineral crystallization, Dilek and Furnes (2011) developed a first order classification, separating ophiolites as subduction-related and subductionunrelated types. Within their classification, mid-ocean ridge (MOR) type ophiolites show geochemical consistency with normal mid-ocean ridge basalt (MORB). Depending on the proximity to features like mantle plumes, the geochemical affinity may fluctuate from MORB all the way to enriched MORB (EMORB). In contrast, subduction-related ophiolites show a progressive geochemical affinity from MORB-like to Island Arc Tholeiite (IAT) and Boninite in the later stages of SSZ ophiolites (Dilek and Furnes, 2011).

Even though the geochemical affinities expected in ophiolites are well-established, secondary processes occur after the formation of new oceanic crust must also be considered. Hydrothermal systems that transport heat from the magma lenses to the surface interact with the crust resulting in hydrothermal alterations and ocean floor metamorphism (Pearce, 2008; Pearce, 2014 and references therein). Enrichments in large ion lithophile elements (LILE) that are usually attributed to an arc-related fluid interaction between the subducting slab and the mantle wedge, could easily be mistaken with seawater interaction and contamination during the emplacement of hot oceanic crust, and vice versa (Boudier et al., 1988; Nicolas and Boudier, 2003). Therefore, the discrimination between MOR-type ophiolites and SSZ ophiolites has to be done carefully and by integrating several geochemical tools. Consequently, in order to accurately assess the geochemical fingerprinting of ophiolites, it is necessary to look at the fluid-immobile element data. Fluid-immobile elements remain unaltered during weathering and low-temperature alteration. These elements are characterized by high to intermediate charge/radius ratios and include most of the rare-earth elements (REE) and high field strength elements (HFSE) (Pearce, 2014). The concentration of these elements is controlled by the chemistry of the magma 
source and the crystallization processes that occur during the magmatic evolution. Several authors have worked on creating fluid-immobile element proxies, which are compared to element ratios that correlate with a specific geological process (Cann, 1970; Pearce and Cann, 1971; Floyd and Winchester, 1975; Pearce, 1975; Shervais, 1982; Sun and McDonough, 1989; Pearce, 2008).

Another useful parameter for ophiolite characterization is its preserved architecture. Variations of the magma supply and spreading rates can modify the architecture of the new oceanic lithosphere (Nicolas and Boudier, 2003; Dilek and Furnes, 2011). Ishiwatari (1985) linked petrological and compositional features of ophiolites to their genesis and to variations in the spreading rates (Fig. 1). In this regard, the structure and composition of an ophiolites can aid to the elucidation of the paleospreading rate (Cannat, 1996; Godard et al., 2000; Dick et al., 2003; Michael et al., 2003; Godard et al., 2008; Cannat et al., 2009; Till et al., 2012). Additionally, the composition of the constituent peridotites and associated melts can contribute to characterize the origin of an ophiolite. For instance, while harzburgite compositions may represent an uppermost oceanic mantle melt source and higher degrees of partial melting, Iherzolite compositions evidence a deeper oceanic mantle, as they represent more fertile residues subject to lesser degrees of partial melting (Fig. 1) (Jackson and Thayer, 1972; Boudier and Nicolas, 1985; Dilek and Furnes, 2011). Thus, ophiolite segments around the globe provide windows into fossilized melt transport systems that once fed the oceanic or arc crust and upper mantle. The presence of a zone of intense dike emplacement that represents the melt-focusing part of the system is a common feature in these exposed sections of the mantle (Robinson et al., 2008). When present, these dike networks provide an insight to the magmatic origin and geochemical evolution of a particular ophiolite.

Our study presents new ${ }^{40} \mathrm{Ar} /{ }^{39} \mathrm{Ar}$ ages, major and trace element data, and radiogenic isotopes from melts that intruded the Santa Elena Ophiolite, located in the northwestern Pacific coast of Costa Rica. This ophiolite represents an emplaced fragment of $250 \mathrm{~km}^{2}$ of upper mantle lithologies 
overthrusting an ancient accretionary complex (Tournon, 1994; Baumgartner and Denyer, 2006; Denyer et al., 2006; Gazel et al., 2006; Denyer and Gazel, 2009; Tournon and Bellon, 2009; Escuder-Viruete and Baumgartner, 2014) (Fig. 2a). Occurrences of diabase dikes around the peninsula are frequent, however the well-preserved diabase dike transport system is largely exposed in two different sections of this ophiolite: the northwestern swarm and the southeastern swarm (Fig. 2c). In both outcrops, the diabases intrude Iherzolite peridotite (Gazel et al., 2006; Tournon and Bellon, 2009). The goal of this integrated structural, geochemical and petrological analysis of the diabase melt-focusing system is to elucidate the magmatic origin and evolution of the Santa Elena Ophiolite and the implications of its origin in the understanding of melt transport and the evolution of the lithospheric mantle.

\section{Geotectonic Background of the Santa Elena Ophiolite}

Costa Rica is currently situated near the triple junction of the Cocos, Caribbean and Nazca plates (DeMets, 2001). Across the Middle American Trench, the Cocos plate is being subducted underneath the Caribbean plate resulting in an active volcanic front (Saginor et al., 2011; Saginor et al., 2013) (Fig. 2b). A series of oceanic complexes have been accreted onto the Caribbean Plate along the Pacific side of Costa Rica including the Santa Elena Ophiolite (Tournon et al., 1995; Hauff et al., 2000; Hoernle et al., 2004; Denyer and Gazel, 2009; Herzberg and Gazel, 2009; Buchs et al., 2013). Several authors correlated the Santa Elena Ophiolite with other serpentinized peridotite locations along the Costa Rica-Nicaragua border suggesting that it represents an E-W suture zone between different tectonic blocks (Tournon et al., 1995; Hauff et al., 2000; Baumgartner et al., 2008; Denyer and Gazel, 2009).

The Santa Elena Ophiolite, constitutes a preserved fragment of the upper mantle that includes evidence for at least two different magmatic intrusive events. The oldest event is constituted by 
decimetric to centimetric pegmatitic gabbroic veins that intrude the Iherzolite without showing any sign of cooling margins, suggesting that they were emplaced when the peridotite was still at high temperatures and in a plastic state (Gazel et al., 2006). The second and younger event is the diabase dike melt-focusing system, which crops out along the peninsula (Figs. 2 and 3); generally presenting cooling margins in contact with the peridotite. The pillow basalts from Murcielago Islands ( $110 \mathrm{Ma}$; Hauff et al., 2000) do not show a clear lithological relation to the rest of the Santa Elena Ophiolite. Even though they have been interpreted as the uppermost basaltic sequence in agreement with ophiolite architectural models, the contact between this unit and the peridotite cannot be observed in the field. These pillow lavas are probably related to other pillow basalts and mafic lithologies in the Nicoya peninsula included in the Nicoya Complex (Dengo, 1962). This complex is interpreted as segments of oceanic plateaus and the Caribbean Large Igneous Province (CLIP), with geochemical affinities that are unrelated to the Santa Elena Ophiolite (Sinton et al., 1997; Hoernle et al., 2004; Geldmacher et al., 2008).

The Santa Elena ophiolite is overlain by Campanian (Upper Cretaceous) rudists-bearing reef limestones (Fig. 1a) (Meschede and Frisch, 1994; Gazel et al., 2006; Baumgartner et al., 2008; EscuderViruete and Baumgartner, 2014) suggesting that it was emplaced during the Upper Cretaceous with the peridotitic complex at the hanging-wall and an igneous-sedimentary complex at the footwall, known as the Santa Rosa Accretionary Complex (Baumgartner and Denyer, 2006; Denyer and Gazel, 2009; Buchs et al., 2013). A unit of layered gabbros (see Fig. 2a) has also been identified at the footwall (Tournon and Azéma, 1980; Hauff et al., 2000; Arias, 2002); this unit yielded an ${ }^{40} \mathrm{Ar} /{ }^{39} \mathrm{Ar}$ age of $124 \pm 4.1 \mathrm{Ma}$ (Hauff et al., 2000). Previous work from Gazel et al. (2006) interpreted a suprasubduction zone origin for the Santa Elena ophiolite, considering the layered gabbros unit as a part of the ophiolite. Here this interpretation is revised in light of the new modern analytical data and our detail geologic mapping, as 
the layered gabbros unit belongs to the footwall, in a highly deformed shear zone bellow the overthrusting ophiolite (see Fig. 2a).

Based on spatial relations between the lithological units that compose Santa the Elena Ophiolite at least two rotation events can be identified in its geologic record. The pillow basalts from Murcielago Islands display a near $80^{\circ}$ tilt towards the north, while the northern Cretaceous (Campanian) to Paleogene sedimentary cover show a dipping angle of $50-40^{\circ}$ towards the north (Fig. 2a). However, the Plio-Pleistocene ignimbrite veneer appears unaffected by the rotation (dipping angles of $5^{\circ} \mathrm{E}$ ). These relative structural disposition suggests that the two tilting events (one pre-Campanian age and the second one roughly in the Upper Eocene) affected the entire sequence for a current net rotation of $80^{\circ}$ towards the north (Denyer et al., 2006; Denyer and Gazel, 2009).

\section{Materials and methods}

\subsection{Structural methods and peridotite/dike determinations}

Diabase dikes are exposed along the coasts and riverbeds of the Santa Elena Ophiolite intruding the peridotite at a variable density of diabase vs peridotite between localities (Fig. 2a). A spatial analysis was performed along the northwestern and southern coasts of the peninsula in order to quantitatively determine the dike density, dike orientation, and structural relationships (Fig. 2a and c). We collected a continuous photographic record and structural measurements (strike/dip angles) of all the diabase dike outcrops on the coast. The data were corrected using the program Win-TENSOR (Delvaux and Sperner, 2003) to account for a tectonic $80^{\circ}$ tilt of the entire complex towards the north in order to obtain the original strike and dip angle of the diabase dikes. This tilt creates an apparent $80^{\circ}$ increase in the dip 
angles of the dikes intruding the block (Table TS1, Supplementary Materials). The continuous photographic record from the coastal outcrops was used to generate panoramic sections of the peninsula (Fig. 3). We carried out a 2D analysis, which included calculation of Cartesian areas in each of the panoramic images created. Considering the rock exposure areas of every outcrop as the total area $(100 \%)$ we calculated the relative abundance of peridotite and diabase. We focused the analysis on the areas that display a continuous occurrence of peridotite and diabase (i.e., along the NW and SE coast of Santa Elena peninsula) (Fig. 2a, c).

\subsection{Samples and analytical methods}

Fresh diabase dikes were sampled from coastal exposures and riverbeds in the Santa Elena Ophiolite. Outcrop location, GPS coordinates, and structural data are reported in Table TS1 (Supplementary Materials). We also sampled pegmatitic gabbroic veins to constrain the timing of the evolution of this ophiolite given the spatial relationship between the units.

Using a rock saw fresh pieces of the samples were cut and later crushed into gravel, cleaned with deionized water and dry-sieved to get rock chips of $425-300 \mu \mathrm{m}$ in diameter. To obtain the ${ }^{40} \mathrm{Ar} /{ }^{39} \mathrm{Ar}$ data, the groundmass and mineral separates were irradiated for 60 hours at the Oregon State University TRIGA-type reactor in the Cadmium-Lined In-Core Irradiation Tube (Tables TS2 a to d, Supplementary Materials). At the University of Wisconsin-Madison Rare Gas Geochronology Laboratory, incremental heating experiments were conducted using a 25 Watt $\mathrm{CO}_{2}$ laser. Each step of the experiment included heating at a given laser power, followed by an additional $10 \mathrm{~min}$ for gas cleanup. The gas was cleaned with two SAES C50 getters, one of which was operated at $\sim 450{ }^{\circ} \mathrm{C}$ and the other at room temperature. Blanks were analyzed after every second laser heating step, and were less than $5 \times 10^{-20} \mathrm{~mol} / \mathrm{V}$ for ${ }^{36} \mathrm{Ar}$

and $2 \times 10^{-17} \mathrm{~mol} / \mathrm{V}$ for ${ }^{40} \mathrm{Ar}$, respectively. Argon isotope analyses were performed using a MAP 215-50, 
and the isotope data was reduced using ArArCalc software version 2.5 (http://earthref.org/ArArCALC/). Ages were calculated from the blank-discrimination and decay-corrected Ar isotope data after correction for interfering isotopes produced from potassium and calcium in the nuclear reactor (Table TS2, Supplementary Materials). Ages are reported with $2 \sigma$ uncertainties (includes the J uncertainty) and are calculated relative to a Fish Canyon standard age of $28.201 \pm 0.046 \mathrm{Ma}$ (Kuiper et al., 2008) and a value for $\lambda^{40} \mathrm{~K}$ of $5.463 \pm 0.107 \times 10^{-10} \mathrm{yr}^{-1}$ (Min et al., 2000) (Tables TS2 a to d, Supplementary Materials).

For major and trace element analyses, alteration-free rock chips were selected under a stereoscope microscope and were powdered in an alumina mill. Major element (wt\%) concentrations were measured by X-ray fluorescence (XRF; Siemens SR3000 spectrometer) at the University of Auckland following the methods described by Norrish and Hutton (1969). In general, precision for each major element is better than $\pm 1 \%(1 \sigma)$ of the reported value as described by Norrish and Hutton (1969). Trace elements were measured by laser-ablation inductively-coupled-plasma mass-spectrometry (LA-ICP-MS) at the Research School of Earth Sciences, Australian National University, using Excimer LPX120 laser (193 $\mathrm{nm}$ ) and Agilent 7500 series mass spectrometer following the method of Eggins et al. (1998). Samples were run in batches of 15 using the NIST612 glass standard at the beginning and end of each run to calibrate. USGS glass standards BCR-2 and AGV-2 were also run to monitor analytical performance. Three replicate analyses of standard BCR-2 and two replicates for standard AGV-2 indicate precision of $<4 \%$ (RSD) and accuracy better than $8 \%$ confidence level, with the exception of the elements $\mathrm{Ni}, \mathrm{Cu}, \mathrm{Cr}$, La and Ta (Table TS3, Supplementary Materials).

Basaltic glass samples collected from the Murcielago Island pillow basalts rims were selected under a stereoscope microscope, and arranged in a 1-inch round epoxy mount which was later polished for electron microprobe (EMP) analyses. These analyses were performed at the Electron Beam Laboratory at Virginia Tech with a Cameca SX50 Electron Microprobe using a $60 \mu \mathrm{m}$ diameter electron 
beam at a $10 \mathrm{nA}$ current a $15 \mathrm{kV}$ acceleration voltage. Trace element contents were obtained at Virginia Tech LA-ICPMS lab facilities using an Agilent 7500ce ICPMS coupled with a Geolas laser ablation system. Three analyses were performed in each glass using a $90 \mu \mathrm{m}$ diameter spot and at $10 \mathrm{~Hz}$ repetition rate. Standards were run at the start and end of the run to correct for drift. The data was reduced using the USGS standards BCR-2G, BHVO-2G and BIR-1. Replicates of these standards indicate a precision of $<5 \%$ (RSD) and accuracy better than $10 \%$ for the elements analyzed, with the exception of the elements $\mathrm{Ni}$, $\mathrm{Cu}, \mathrm{Cr}, \mathrm{Zn}, \mathrm{Sr}, \mathrm{Ta}, \mathrm{Pb}$ and $\mathrm{U}$ that was better than $30 \%$ (Table TS3, Supplementary Materials).

Radiogenic isotope analyses were conducted in the Geochronology and Isotope Geochemistry Laboratory at the University of North Carolina, Chapel Hill (Table TS3, Supplementary Materials). 500 mg of the selected powdered samples were digested with a mixture of $\mathrm{HF}+\mathrm{HNO}_{3}$ in Teflon beakers. These solutions were placed on a hotplate for three days at a temperature of $165{ }^{\circ} \mathrm{C}$. Each sample was dried and re-dissolved in $\mathrm{HCl}$. After their dissolution three aliquots were separated for $\mathrm{Sr}, \mathrm{Nd}$ and $\mathrm{Pb}$, each one containing $5 \mathrm{mg}$ of sample; these aliquots were dried and re-dissolved in the appropriate acid solution to undergo ion exchange chromatography columns (Gray et al., 2008). The separates were analyzed using a Micromass VG Sector 54 thermal ionization mass spectrometer (TIMS). Strontium measurements were normalized to ${ }^{86} \mathrm{Sr} /{ }^{88} \mathrm{Sr}=0.1194$, and $\mathrm{Nd}$ isotopes to ${ }^{146} \mathrm{Nd} /{ }^{144} \mathrm{Nd}=0.7219$. Standard replicate measurements yielded a mean ${ }^{87} \mathrm{Sr} /{ }^{86} \mathrm{Sr}=0.710257 \pm 0.000022(2 \sigma)$ for NBS 987, a mean ${ }^{143} \mathrm{Nd} /{ }^{144} \mathrm{Nd}=$ $0.512112 \pm 0.000011(2 \sigma)$ for JNdi-1, and a mean ${ }^{206} \mathrm{~Pb} /{ }^{207} \mathrm{~Pb}=1.0940 \pm 0.0003(2 \sigma)$ for NBS-981 with a mean fractionation correction of $0.098 \pm 0.008 \%$ per amu (Coleman et al., 2004; Gray et al., 2008).

\section{Results}

\subsection{Structural analysis of the diabase unit}


After correcting for the $80^{\circ}$ northward tilt of the ophiolite determined in the field the general strike orientation for the diabase dikes throughout the Santa Elena Ophiolite is NNE in a sub-parallel arrangement. The resulting dip angles reflect a predominance of angles higher than $60^{\circ}$, with a primary population of dikes dipping between $70^{\circ}$ and $90^{\circ}$. Evidence of this disposition is largely visible at the NW coast of the peninsula (Fig. 2a).

The northwestern dike swarm (Fig. 2a) represents the higher density of diabase intruding the peridotite in the entire ophiolite with a dip between $70^{\circ}$ and $80^{\circ}$ (Fig. 2c). Our density analysis suggests that in this section there is a significant increase of diabase dikes from $\sim 78 \%$ to $\sim 92 \%$ (relative to the peridotite) towards the southwest in the direction of Punta Santa Elena (Fig. 2a), where the peridotites became boudins embedded in the net of diabase dikes.

The outcrops along the southern coast of the peninsula are predominantly composed of peridotite with scarcer occurrences of diabase dikes. In this area the presence of diabase versus peridotite is less than $20 \%$ (Fig. 2a). The preferential strike direction for the southeastern dike swarm is towards the NW, with a secondary population striking ENE-WSW. In this area, the arrangement of the intrusions is clearly not parallel; however, most of the dip angles remain in a range between $60^{\circ}$ and $90^{\circ}$ (Fig. 2c). Additionally, other diabase intrusions measured in the interior of the peninsula yielded a preferential strike of NNE-NNW with sub-vertical dip angles (Fig. 2a).

\subsection{Geochronology and geochemistry data}

The four new ${ }^{40} \mathrm{Ar} /{ }^{39} \mathrm{Ar}$ ages collected in this work yielded an average age of $121 \mathrm{Ma}$ (considering the uncertainty within the measurements) for the diabase dike intrusion event (Tables S2 a to d). Diabase samples collected from the NW end of the Santa Elena Peninsula yielded $126.6 \pm 2.1$ Ma to 116 $\pm 5.1 \mathrm{Ma}$ (Fig. 2a). A sample from the southern coast of the peninsula yielded an age of $118.7 \pm 3.5 \mathrm{Ma}$. 
Also, a diabase sample from the inner part of the ophiolite was analyzed to achieve a good geographical distribution throughout the peninsula; this sample provided an age of $124.7 \pm 3.0 \mathrm{Ma}$. One of the pegmatitic gabbroic veins sampled that intruded the peridotite when it was still hot and plastic (Gazel et al., 2006) yielded an age of $131 \pm 3.8 \mathrm{Ma}$ (Table TS2e). Detailed step-heating experiments and ${ }^{40} \mathrm{Ar} /{ }^{39} \mathrm{Ar}$ spectra for all the samples are available in Tables TS2 a to e (Supplementary Materials).

For this study we report 18 new major and trace element analyses for diabase dikes and 5 for Murcielago Islands basaltic glasses (Table TS3, Supplementary Materials). The compositions of the diabase dikes are basaltic and belong to the tholeiitic magmatic series (Fig. 4a, b). Petrographically, they are aphyric and consist of a fine grained equigranular ensemble of semi-euhedral clinopyroxene and plagioclase and minor olivine, with a predominately ophitic texture characteristic of mafic hypabyssal intrusions. The rim glasses from Murcielago Islands are basaltic-andesite in composition and also belong to the tholeiitic series (Fig. 4a, b).

Along with the new analyses provided in this work from the diabase dikes, we also compiled geochemical data from previous studies (Kussmaul et al., 1982; Tournon, 1984; Wildberg, 1984; Meschede and Frisch, 1994; Tournon, 1994; Ragazzi, 1996; Beccaluva et al., 1999; Hauff et al., 2000; Arias, 2002; Tournon and Bellon, 2009) (Table TS3, Supplementary Materials), which are plotted as a shaded area in Fig. 4. Major element data were plotted against MgO (Fig. 5 and 6) to evaluate differentiation trends in the sample suite collected. Trace element data, normalized to a primitive mantle composition (McDonough and Sun, 1995) show a depleted composition in light rare earth elements (LREE) and a flat pattern in the heavy rare earth elements (HREE), suggesting a garnet-free, shallow mantle source (e.g. Salters and Stracke, 2004) (Fig 7). Elevated concentrations in fluid-mobile large ion lithophile elements (LILE) such as $\mathrm{Ba}, \mathrm{K}$ and $\mathrm{Sr}$ are indicative of seafloor alteration (Staudigel et al., 1981; Staudigel et al., 1996; Staudigel, 2003). Thus, to avoid the signature of ocean floor alteration, only fluid immobile ratios were used to generate the discrimination diagrams shown in Fig. 8 . The 
Murcielago Islands pillow basalt glass rims show a more enriched incompatible-element signature compared to that of the Santa Elena diabase dikes (Fig 7e) which is almost identical to the basaltic glasses that belong to the Caribbean Large Igneous Province (CLIP) and other basaltic suites found in Nicoya Peninsula (Hauff et al., 1997; Sinton et al., 1997; Hauff et al., 2000; Hoernle et al., 2004).

The new $\mathrm{Sr}, \mathrm{Nd}$, and $\mathrm{Pb}$ radiogenic isotope analyses were carried out using the freshest samples of the diabase dikes, however Sr isotopes could still be affected by any low-grade ocean floor alteration, and thus explaining the spread in the data (Table TS3). The measured diabase dikes isotope values range from 0.70283 to 0.70396 in ${ }^{87} \mathrm{Sr} /{ }^{86} \mathrm{Sr} ; 0.51299$ to 0.51341 in ${ }^{143} \mathrm{Nd} /{ }^{144} \mathrm{Nd}$; 18.149 to 18.536 in ${ }^{206} \mathrm{~Pb} /{ }^{204} \mathrm{~Pb}$;

15.500 to 15.595 in ${ }^{207} \mathrm{~Pb} /{ }^{204} \mathrm{~Pb}$; and 37.839 to 38.166 in ${ }^{208} \mathrm{~Pb} /{ }^{204} \mathrm{~Pb}$ (Fig. 9). These measured $\mathrm{Sr}-\mathrm{Nd}-\mathrm{Pb}$ ratios were then calculated to the initial (in) eruptive ratios using the parent/daughter ratios from elements reported in Table TS3 and an average age of 121 Ma (Table TS3, Supplementary Materials). Age corrected ratios representative of the mantle source were then projected to $121 \mathrm{Ma}$ using parent/daughter ratios obtained inverting the source composition from the most primitive diabase dike sample (A-28-7-05) to recreate the evolution of the source in $121 \mathrm{Ma}$ and compared with recently erupted material. The model was done using aggregated fractional melting equations (Shaw, 1970) with a modal composition of $50 \%$ olivine, $25 \%$ orthopyroxene, $20 \%$ clinopyroxene and $5 \%$ spinel and the partition coefficients compiled by Kelemen et al. (2003). This data were plotted in Fig. 9 and discussed in section 5.4 .

\section{Discussion}

5.1 Architecture of the Santa Elena Ophiolite: diabase melt focusing zone analysis 
The arrangement of dike intrusions in different tectonic environments provides important insight into the type of melt emplacement that occurred at a given location. For instance, radial arrangements of dikes typically indicate environments such as arc volcanoes or ocean islands (i.e. Ancochea et al., 2008; Acocella and Neri, 2009; Maccaferri et al., 2011). Whereas, in environments characterized by extension regimes, melts are likely to migrate perpendicularly to the direction of the minimum compressive stress (Macdonald, 1982; Gudmundsson, 1990a; Paquet et al., 2007; Gudmundsson, 2011), resulting in sub-parallel to parallel dike assemblages. This commonly occurs at mid-ocean ridges and back arc basins, where the intrusions normally show similar strike orientations perpendicular to extension as well as parallel sub-vertical arrangements.

Ophiolites, as preserved fragments of extension environments (e.g., mid-ocean ridges, back arc basins), usually display sheeted dike complexes composed by dike-intruding-dike structures of tholeiitic composition, that have been interpreted as the feeder channels between magma chamber/lenses and the overlying extrusive oceanic crust (Robinson et al., 2008 and references therein). At fast spreading ridges, such as in the exposed section at Hess Deep in the Pacific, the sheeted dike complex is a welldeveloped feature of the oceanic crust suggesting a high spreading rate and a steady magma supply (Stewart et al., 2005; Veloso et al., 2014). In contrast, at slow ( $<60 \mathrm{~mm} / \mathrm{yr}$ full rate), and ultraslow spreading ( $<20 \mathrm{~mm} / \mathrm{yr}$ full rate) ridges the magma generation is slow and tectonic extension and detachment faulting are the predominant trigger for melting, resulting in the absence of a welldeveloped sheeted dike complex (Snow and Edmonds, 2007; Robinson et al., 2008; Lagabrielle et al., 2015). The Santa Elena Ophiolite preserves a relatively high density of diabase intrusions, however, in contrast to sheeted dike complexes, it lacks the typical gabbro-sheeted dike-basalt sequence and instead the dikes intrude the lithospheric mantle peridotite directly and there is not an overlying welldeveloped basaltic crust. 
The absence of horizontal intrusions indicates that during melt migration no rheological or mechanical barrier was encountered that led to lateral migration. The dike swarms exhibit an almost vertical arrangement. Since dike emplacement tends to follow pre-existing paths, we suggest that this vertical to sub-vertical emplacement corresponds to the location of previous extension fractures, perpendicular to the direction of the minimum compressional stress. The results presented in this work indicate that the Santa Elena Ophiolite was formed in a tectonic environment subject to extension, with an expected dike arrangement of a mid-ocean ridge system (e.g. Gudmundsson, 1990b; Gudmundsson, 2011)

Mid-ocean ridge systems with slow and ultra-slow spreading rates can account for the emplacement of almost exclusively vertical intrusions due to limited melt productivity (Michael and Cornell, 1998; Dick et al., 2003; Gudmundsson, 2011). In these environments, dikes form at greater depths intruding directly in the lithospheric mantle. Even though it has been recognized that the rheological barrier of the crust-mantle boundary favors the formation of melt ponding (i.e., magma chambers or lenses) (Gudmundsson, 2011), there is no field evidence for such melt accumulations in the Santa Elena Ophiolite. Commonly, melt migration in slow and ultra-slow spreading mid-ocean ridges show little and generally deep melt ponding as a consequence of the low rates of melt productivity in this tectonic environment (Michael and Cornell, 1998). Melt forming in such conditions will travel along paths of minimum stress like the extensional fractures and faults inherent to slow and ultra-slow spreading ridges which are essentially vertical as observed in the Santa Elena Ophiolite.

As melts are transported from the melt generation zone to the axis of extension, the frequency of intrusions decreases while their size and width increase (Kelemen et al., 1997; Kelemen et al., 2000). In the Santa Elena Ophiolite, we encountered a high spatial density of intrusions combined with distinct coalescent dikes as shown in Fig. 3. The presence of Iherzolitic peridotite and the coalescing channels of diabase correlate with what would be expected at greater depths of the melt transport system in an 
extensional environment, characterized by a scarce magmatic supply at deeper levels in the lithospheric mantle (see Fig. 1). Moreover, this ophiolite lacks of an extrusive well-developed basaltic crust on top of the sequence which supports the interpretation that this ophiolite corresponds to a slow to ultra-slow spreading center (Dick et al., 2003; Cannat et al., 2009; Sauter et al., 2011). The absence of a welldeveloped gabbroic crust is also evident in this ophiolite. This is a noted characteristic in ultraslow spreading ridges, where the reduced melt production can lead to a small to nearly inexistent gabbroic crust (Jokat et al., 2003; Michael et al., 2003).

\subsection{Geochronology data}

The spatial relationships between the diabase and gabbroic intrusions of the Santa Elena Ophiolite become clearer in the light of the new ${ }^{40} \mathrm{Ar} /{ }^{39} \mathrm{Ar}$ data collected in this study. Both units postdate the formation of the peridotitic massif, but the pegmatitic gabbroic veins are the first magmatic event to occur (evidenced by cross-cutting relationships), at circa $131 \pm 3.8 \mathrm{Ma}$. This event is particularly interesting since the field evidence suggests that there are no cooling margins between the pegmatitic gabbro veins and the host peridotite. This implies that during the emplacement the host rock and the intrusion were roughly at the same temperature. Most likely the gabbroic melts infiltrated when the peridotite was still under plastic deformation conditions (Gazel et al., 2006).

On the other hand, the diabase dikes present clear cooling margins suggesting that by the time the diabase magmatic event occurred (roughly circa $121 \mathrm{Ma}$ ) the peridotite had already reached lithospheric temperatures. Consequently, the ${ }^{40} \mathrm{Ar} /{ }^{39} \mathrm{Ar}$ ages obtained in this study constrain the cooling of the ophiolite massif to sometime between $131 \pm 3.8 \mathrm{Ma}$ and the youngest of the diabase dikes, $116 \pm$ 5.1 Ma, which coincides with a Barremian to Aptian age. This interpretation is in good agreement with the age constraints from other authors based in the rudist-bearing reef ages, that also places the 
tectonic emplacement no earlier than Campanian (Upper Cretaceous) (Meschede and Wolfgang, 1998; Gazel et al., 2006; Baumgartner et al., 2008; Escuder-Viruete and Baumgartner, 2014).

\subsection{Fractional crystallization models and implications for crystallization pressures}

The architecture of the Santa Elena Ophiolite along with the variable observed cooling textures suggests that the diabase dikes were emplaced at depths within the lithospheric mantle (Fig. 3). In order to better determine these depths, we used Petrolog3 (Danyushevsky and Plechov, 2011) to produce models that simulate the fractional crystallization processes at different pressures (results in Fig. 5 and 6). For these calculations, we used the olivine (ol), plagioclase (plag) and clinopyroxene (cpx) models of Danyushevsky (2001). The cotectic crystallization was modeled at a $100 \%$ fractionation of these minerals in equilibrium with a liquid $(L+o l+p l a g+c p x)$. When more than one mineral phase crystallizes together, the software calculates a "pseudoliquidus" temperature (PST), which is the highest recorded temperature of crystallization of the two or three mineral phases. These PST's can be plotted as liquid lines of descent (LLD), where every discontinuity in the line indicates a new crystallizing mineral phase (Fig. 5 and 6). The calculations were made using the QFM buffer of oxygen fugacity according to the model of Kress and Carmichael (1988). We created models from a pressure range of $0.001 \mathrm{GPa}$ (1 atm) to $1.0 \mathrm{GPa}$, in $0.2 \mathrm{GPa}$ increments, keeping the pressure constant during each run. The amount of melt extracted in each step was $0.01 \%$; this small calculation step improves the accuracy of the model (Danyushevsky, 2001). The calculations stopped when the melt MgO content reached 3 wt\%.

To evaluate our initial hypothesis of a mid-ocean ridge origin for the melts that formed the diabase dikes, we input a primary magma composition for MORB (East Pacific Rise, EPR) from Herzberg and O'Hara (2002), as well as a primary magma calculated from our most primitive diabase composition

(Fig. 6). Albeit, the resulting LLDs of these models plotted in bivariate major element diagrams were able 
to reproduce experimental MORB glasses at the same range of pressures (see references in the figure caption), they failed to reproduce the crystallization trends and compositional changes that can be observed in the diabase dike suite. Because an EPR-MORB starting composition and our most primitive diabase sample did not describe the differentiation path of our samples, the input composition was empirically modified by an optimization method to include 0.5 wt $\% \mathrm{H}_{2} \mathrm{O}, 50.06$ wt $\% \mathrm{SiO}_{2}$ and 2.83 wt\% $\mathrm{Na}_{2} \mathrm{O}$ to the initial EPR-MORB. This final composition (Table TS4, Supplementary Materials) successfully recreates and explains the compositional evolution of the diabase dikes. One important result from this modeling is that the diabase dike compositions cannot be reproduced by anhydrous MORB (Fig 6). The effect of small amounts of $\mathrm{H}_{2} \mathrm{O}$ on MORB melt compositions results in a displacement of the cotectic points (the discontinuities in the LLD) due to the suppression of plagioclase crystallization relative to olivine and clinopyroxene (see Fig. 6a through e) (Danyushevsky, 2001). The estimated amount of $\mathrm{H}_{2} \mathrm{O}$ (0.5 wt\%) necessary to explain our data is atypical for MORB, however, it still falls into the high endmember of hydrated MORB magmas (Hirth and Kohlstedt, 1996; Danyushevsky, 2001; Asimow and Langmuir, 2003).

The $\mathrm{SiO}_{2}$ variation of the diabase dike suite is controlled by olivine partitioning as a function of temperature and pressure (Langmuir et al., 1992). The crystallization of plagioclase and pyroxene is most likely responsible for the increase in $\mathrm{SiO}_{2}$ contents at low pressures $(<0.4 \mathrm{GPa})$. In the diabase dike samples, the cotectic crystallization of olivine and plagioclase is suggested by a positive correlation between $\mathrm{MgO}$ and $\mathrm{Al}_{2} \mathrm{O}_{3}$ (Fig. $5 \mathrm{~b}$ ). Using a MORB composition, this correlation tends to be positive because increasing levels of fractionation will lead to a decrease of $\mathrm{MgO}$ and $\mathrm{Al}_{2} \mathrm{O}_{3}$ in the melt due to the crystallization of olivine and plagioclase, respectively (Danyushevsky, 2001). As the pressure increases, the liquids in equilibrium with $\mathrm{Ol}+\mathrm{Plag}+\mathrm{Cpx}$ will increase their $\mathrm{Al}_{2} \mathrm{O}_{3}$ content and this can lead to a higher modal plagioclase content (Herzberg, 2004). $\mathrm{FeO}_{\mathrm{t}}$ shows the expected enrichment during fractionation of tholeiitic magmas (Zimmer et al., 2010). 
$\mathrm{CaO}$ vs. MgO systematics (Fig. $5 \mathrm{c}$ and 6 ) can be used to evaluate whether or not a melt has crystallized clinopyroxene because $\mathrm{CaO}$ contents increase during the L+OI and L+Ol+Plag steps of crystallization and promptly decrease as soon as the liquid starts to crystallize Ol+Plag+Cpx. The sensitivity of $\mathrm{CaO}$ to pressure effects was evaluated by Langmuir et al. (1992) and Herzberg (2004). The Santa Elena diabase dikes plot within the LLDs modeled from 1 atm to $1 \mathrm{GPa}$ (Fig. 5); however, a larger set of samples plot at pressures >0.4 GPa. We also plotted our data onto a projection of liquids for the equilibrium $\mathrm{L}+\mathrm{Ol}+\mathrm{Plag}+\mathrm{Cpx}$ into the plane Anorthite-Diopside-Enstatite following the methods of Herzberg and O'Hara (1998) and Herzberg (2004) (Fig. 5e). In this projection the pressures of crystallization of most of the diabase dikes also yielded $>0.4 \mathrm{GPa}$, further supporting a deep origin for the dikes. Although these values are model-dependent and absolute pressures are not easy to obtain, our results are consistent with deep crystallization in the lithospheric mantle rather than at crustal levels, as it is obvious in the field exposures (Fig. 3).

The data from the Santa Elena Ophiolite were also compared to geochemical data from midocean ridges globally, compiled by Gale et al. (2013). Fast spreading ridges group around the LLDs that belong to pressures from $1 \mathrm{~atm}$ to $0.4 \mathrm{GPa}$, which can be correlated with shallow depths of melt crystallization. Correlations between spreading rate and depth of crystallization have been noted by other authors (Grove et al., 1993; Michael and Cornell, 1998; Herzberg, 2004; Escartin et al., 2008); and in general, slower spreading rates are associated with deeper crystallization. In this respect, the Santa Elena Ophiolite diabase dikes show a range of pressures of crystallization that are consistent with deep crystallization environments. These pressures $(>0.4 \mathrm{GPa}$ ) correspond to depths $>15 \mathrm{~km}$ (assuming an average density of $\sim 3.0 \mathrm{~g} / \mathrm{cm}^{3}$ for the oceanic lithosphere). The results are in good agreement with the estimated pressures of partial crystallization at the top of the melting regime in slow and ultra-slow spreading ridges (Herzberg, 2004), thus, providing supportive information for a slow to ultra-slow spreading rate for the extensional environment preserved in the Santa Elena Ophiolite. 


\subsection{Trace element signatures and tectonic implications}

In order to further understand the tectonic environment in which the Santa Elena Ophiolite formed, the diabase dike trace element compositions were normalized to a Primitive Mantle composition (McDonough and Sun, 1995). Primitive-normalized data are depleted in the most incompatible elements, such as the LREE, consistent with the trace element composition of a depleted MORB-like source (Salters and Stracke, 2004) (Fig. 7a). When the trace element patterns of the Santa Elena Ophiolite are compared with other primitive-normalized trace element compositions of other extensional tectonic environments, our results are similar to signatures that are found in slow to ultraslow spreading ridges and back-arc spreading centers, but always at the depleted end of these environments consistent with a normal MORB signature (Fig. 6).

Because magmas record information about their original tectonic setting of formation in their trace-element signatures, a series of geochemical proxies have been identified that can be used to discriminate paleo-tectonic environments (e.g., Pearce, 2008 and references therein). In order to better determine the tectonic environment that formed the Santa Elena Ophiolite, we used fluid-immobile elements to distinguish between a mid-ocean ridge environment and a subduction influenced environment. For comparison, we compiled geochemical data from various ophiolites (Mayari-Baracoa Ophiolitic Belt, Oman, Newfoundland, Josephine, Mirdita, Macquarie Island, Ingalls, Tangihua, Shuanggou, Kizildag, Anatolia, Troodos, Duarte, Loma La Monja, La Desiderade; see Table TS3 for data and references) as well as trace element data from other extensional environments (Atlantis Massif, Atlantis Bank, San Souci volcanic formation, Atlantic oceanic crust of ca. $121 \mathrm{Ma}$, ultra-slow spreading centers, back-arc basins; Table TS3) and plotted along with the results from the Santa Elena Ophiolite and the Murcielago Islands pillow basalts in Fig. 8. 
In these fluid-immobile element systems the mantle array is defined by where MORB-OIB data plots. Data that plots away from this array suggests the influence of subduction processes or crustal interaction, as for example, samples that belong to SSZ ophiolites such as Oman, Newfoundland, Ingalls, Anatolia, and Kizildag, plot away from the mantle array as indicated by the "subduction interaction" vector as shown in the plot of $\mathrm{Zr} / \mathrm{Nb}$ vs. Ti/Th (Fig. 8a). Similarly, as shown in the $\mathrm{Ce} / \mathrm{Nb}$ vs. Th/Nb diagram (Fig. 8b), the subduction influenced samples plot towards higher Ce and higher Th. Ce can be considered as a proxy for $\mathrm{H}_{2} \mathrm{O}$ content, since both elements have a similar incompatible behavior during melting (Saunders et al., 1988). This diagram provides an easy visualization of the effect of increasing subduction interaction, which is especially evident in SSZ ophiolite samples. Fig. 8c shows the Th/Yb vs. $\mathrm{Nb} / \mathrm{Yb}$ diagram first developed by Pearce (2008). Th and $\mathrm{Nb}$ are well-known proxies for subduction input within a system, as Th is carried by subduction fluids (especially sediment recycling) and $\mathrm{Nb}$ is retained by a residual phase in the subducting slab (Wood et al., 1979; Pearce, 2008; Pearce, 2014). Thus, samples influenced by subduction fluids trend towards higher Th contents and lower $\mathrm{Nb}$ contents relative to the mantle array. This is why samples coming from back-arc basins plot parallel to and higher than the mantle array and SSZ ophiolites also show an upward trend.

Our results indicate that the Murcielago Islands pillow basalts plot well into the mantle array limits, trending towards the enriched endmember of MORB. Meanwhile, the Santa Elena Ophiolite diabase dikes plot on the limits between the data from back-arc basins and slow to ultra-slow spreading ridge MORB consistent with our previously discussed major element results. In comparison with the global compilation, our data also show similarities with the Atlantis Massif, Atlantic oceanic crust, and the Atlantis Bank (Fig. 8a, b and c). The location that shows the most consistency with the diabase dikes are the tholeiites from the Mirdita Ophiolite in Albania. This is a Jurassic ophiolite interpreted as a transition from a MORB to a SSZ environment (Dilek and Furnes, 2009). Santa Elena intrusions are also geochemically similar to the Continental Margin Ophiolite classification of Dilek and Furnes (2014) which 
plot on the NMORB field of the mantle arrange and towards the upper limit. Therefore, our diabase dike samples resemble a MORB-type magmas that show only a "hint" of subduction interaction.

\subsection{Mantle signatures from radiogenic isotopes}

Radiogenic isotopes are a reliable way to evaluate the source of a given sample, since they do not fractionate during magmatic processes such as melting or crystal fractionation. In terms of radiogenic isotopes, MORB was thought to be derived through melting of a homogeneous mantle reservoir (the upper mantle). However, more recent studies reveal the significant variations in the radiogenic isotope ratios indicating that it is more likely that they are generated from mantle sources that are heterogeneous (Salters and Stracke, 2004; Workman and Hart, 2005). Isotopic variability in MORB from fast spreading and slow spreading ridges may differ depending on the mixing mechanisms intervening in the systems. In this regard, small-scale convection contributes to mixing of different sources at slow spreading ridges, producing geochemically homogeneous reservoirs (Samuel and King, 2014).

The new age corrected (accounting for the source evolution in 121 Ma) data from the Santa Elena Ophiolite mafic dikes are presented in Fig. 9. The diabase dikes share isotopic signatures that resemble those from back-arc basins and slow to ultra-slow spreading ridges and are separate from those of fast spreading ridges (Fig. 9). This is consistent with the results discussed above for major and trace element compositions. The diabase samples yield ${ }^{87} \mathrm{Sr} /{ }^{86} \mathrm{Sr}$ values between 0.70285 and 0.70357 (Fig. 8a), which are on the higher end for NMORB but not as high as the range of EMORB. Also, they overlap with the lower ${ }^{87} \mathrm{Sr} /{ }^{86} \mathrm{Sr}$ values for back-arc basins. The $\varepsilon N d$ values obtained for the diabase dikes range between +6 and +12 , and when plotted against ${ }^{87} \mathrm{Sr} /{ }^{86} \mathrm{Sr}$ they overlap with data from slow and ultraslow spreading ridges, and with data from back arc basins to a lesser extent (Fig. 9a). 
The data also show that the diabase dikes are more enriched in ${ }^{206} \mathrm{~Pb} /{ }^{204} \mathrm{~Pb},{ }^{207} \mathrm{~Pb} /{ }^{204} \mathrm{~Pb}$ and ${ }^{208} \mathrm{~Pb} /{ }^{204} \mathrm{~Pb}$ than depleted DMM (Fig. 9b, $\mathrm{c}$ and d), following a linear array that suggests a mixture of a depleted component and an enriched component (EMII), most likely due to small-scale convection, a consistent characteristic in slow-spreading systems (Samuel and King, 2014). The EMII mantle reservoir is interpreted as deep mantle storage of metasomatized oceanic lithosphere or sub-continental lithosphere (Workman et al., 2004). Detachment of sub-continental lithosphere may occur during continental break-up (Saunders et al., 1988). Therefore, this isotopic signature can be correlated with the remnants of lithospheric mantle components disseminated during the opening of the Atlantic and the proto-Caribbean ocean. Additionally, the presence and mixing of these likely subduction-modified remnants of the sub-continental lithosphere could account for the subtle subduction signature evident in our samples (see discussion in Gazel et al., 2012).

\subsection{Paleotectonic setting for the Santa Elena Ophiolite formation}

Data presented in this work shows that the Santa Elena Ophiolite preserves structural and geochemical evidences for an extension environment of formation. Whether it is a mid-ocean ridge or a back-arc basin environment is still a matter of further constraints, such as paleomagnetic surveys and detailed tectonic reconstructions. However, the similarities with data coming from back-arc basin tectonic settings like Lau Basin and Marianas (Fig. 8) suggest that Santa Elena Ophiolite might have originated from an analogous setting.

Moreover, the Santa Elena Ophiolite characteristics are comparable with the structure and geochemical affinities present in some oceanic core complexes (OCC). For instance, the Godzilla Megamullion located in the extinct Parece Vela Rift in the back-arc basin of the Marianas (Fig. 10) consists of an exposed lower crust to mantle sequence of plutonic rocks including peridotites (Iherzolites 
and harzburgites), gabbroic and diabase intrusions and a varying presence of a basaltic crust (Ohara et al., 2001; Ohara et al., 2003; Loocke et al., 2013). Sanfilippo et al. (2013) also mention that the basalts retain their MORB affinity and their REE and isotope compositions appear enriched by a minor slab component. OCCs like the Kane Megamullion (Dick et al., 2008) and the Atlantis Massif (Blackman et al., 2002) in the Mid-Atlantic Ridge, or the Atlantis Bank in the Indian Ridge (Baines et al., 2003) also show mantle sequences consisting in peridotites, diabase dikes and to a lesser extent gabbros.

The idea of OCCs being preserved as ophiolites has been suggested by several authors (i.e. Nicolas et al., 1999; Tremblay et al., 2009; Manatschal et al., 2011; Lagabrielle et al., 2015). If Santa Elena is an OCC preserved as an ophiolite, it would explain the lack of a basaltic crust since in many OCCS low magmatic supply is common and the basaltic crust gets variably displaced by the hanging-wall during detachment (Escartín et al., 2003; Dick et al., 2008).

An alternative model for the origin of Santa Elena would be that it represents a fragment of the Mesquito Composite Oceanic Terrane (Baumgartner et al., 2008), a series of accreted Pacific oceanic terranes conformed by mafic and ultramafic lithologies. This explanation is supported by findings of Pacific Radiolarian fauna in different Caribbean locations that pre-dates the opening of the ProtoCaribbean (Baumgartner and Denyer, 2006; Baumgartner et al., 2008; Bandini et al., 2011). This hypothesis however is not mutually exclusive to the OCC origin, since the preservation and emplacement of this fragment of the lithospheric mantle could have happened in the context of accretion of distinct Pacific terranes.

Finally, a Proto-Caribbean origin should also be explored in future studies. Proto-Caribbean remnants have been found along the Great and Lesser Antilles (Lapierre et al., 1999; Marchesi et al., 2006; Escuder-Viruete et al., 2009). For instance, samples from the San Souci Volcanic Group, in Trinidad y Tobago, which have been interpreted as preserved pieces of Proto-Caribbean oceanic crust (Neill et 
al., 2014) show similar fluid immobile element signatures as the diabase dikes explored in this study (Fig.

8).

\section{Conclusions}

Structural and geochemical evidence suggest an extensional environment for the formation of the Santa Elena Ophiolite. The ophiolite architecture shows clear characteristics of mid-ocean ridge origin that include sub-parallel and sub-vertical arrangement of the dikes, coalescing channels of melt, absence of horizontal intrusions, zones of higher density of dikes relative to peridotite. Additionally, the lack of overlaying sequences of developed oceanic crust, the predominant presence of Iherzolite as opposed to harzburgite, and the absence of significant magma chamber or lenses suggest that the Santa Elena Ophiolite is a preserved deep section (in the lithospheric mantle) of a melt-focusing zone in a slow to ultra-slow spreading ridge.

Major and trace element data are also in good agreement with the assessment of the origin of the Santa Elena Ophiolite as a slow/ultra-slow spreading center, possibly with a limited subduction interaction. The calculated pressures of crystallization are more consistent of slow to ultra-slow spreading ridges, where partial crystallization can occur deeper in the mantle since there is a lower magma supply and thus less heat flow. However, as evidenced from our geochemical data, the tectonic environment of formation for Santa Elena Ophiolite, even though it corresponds with an oceanic extension environment, it was not purely a Mid-Ocean Ridge nor a Back-Arc Basin setting sensu stricto, but possibly a combination between both environments. A possible analogous tectonic scenario could be similar to what is found at an oceanic core complex that developed in a back-arc basin, where the 
proximity to transform faults reduces the velocity of the spreading rates and induces detachment which emplaces the lithospheric mantle and the melt-focusing zone of the system at the seafloor.

\section{Acknowledgements}

This project was supported by the National Science Foundation award EAR-1019327 from the Tectonics Program to E. Gazel and the Costa Rican Department of Science and Technology (MICITT) fund FI-157-13 to Pilar Madrigal. Logistics during fieldwork were supported by the University of Costa Rica with project \# 830-B0-242 and ED-2700. We thank M. M. Chavarria and R. Blanco of the Área de Conservación Guanacaste for their valuable support during fieldwork. This paper benefitted from discussions with H. Dick, P. Kelemen and L. Danyushevsky. Revisions by I. Neill and anonymous reviewer significantly improved the submitted manuscript. We also want appreciate the editorial handling and suggestions by $A$. Kerr. 
Figure Captions for printed version:

Figure 1: Two models of the architecture of the oceanic crust modified from Kelemen et al. (2000) and Cannat (1996). A) At a fast spreading ridge, magmatic supply is abundant and melting occurs at shallower levels in the lithosphere; these melts ascend and form coalescing channels (Kelemen, 2000). Melt fractions are higher than at slow spreading ridges, which allow the development of an oceanic crust on top (Cannat et al., 2006). B) At ultra-slow spreading centers, melts are triggered by detachment faulting which drives a much deeper melting regime. Slower magma generation and lower melt fraction are characteristic of this environment. In this model, melt travels along a pre-existing oceanic mantle lithosphere composed predominantly of Iherzolite (Dick et al., 2003; Cannat et al., 2009).

Figure 2: Overview map of the Santa Elena peninsula. A) Geologic map modified by our field observations from Tournon et al. (1994), Gazel et al. (2006) and Escuder-Viruete and Baumgartner (2014); two cross sections are provided to illustrate the spatial relationship between lithologies from $\mathrm{N}$ to $S\left(A-A^{\prime}\right)$ and SW to NE (B-B'). B) Geotectonic setting of the Santa Elena Ophiolite after Denyer and Gazel (2009). C) Structural data for the diabase dikes from the NW dike swarm and SE dike swarm measured and corrected in this study.

Figure 3. Photograph from the diabase dike swarms in the Santa Elena Ophiolite; $\beta$ denotes diabase dikes and $\pi$ peridotite. A) Southeastern diabase swarm; diabase dikes intrude the peridotite in a sub-parallel arrangement. B) Boudins of peridotite created by the intruding diabase. C) Boudins of peridotite northwestern diabase swarm. D) and E) Diabase dikes branching out in the shape of an "inverted bush" at a metric scale. 
Figure 4. Geochemical classification of the diabase dikes of the Santa Elena Ophiolite. A) Total Alkalis-Silica (TAS) diagram (Le Maitre et al., 1989) where the samples from the Santa Elena Ophiolite display a dominant basaltic composition. B) AFM classification diagram (Irvine and Baragar, 1971) suggesting a predominant tholeiitic affinity for the diabase samples. Dark gray circles denote the new data presented in this paper and gray fields includes data compiled from literature (Table TS3). The dashed lines show the compositional range of MORB data (Gale et al., 2013).

Figure 5. Major element variation diagrams for the diabase dikes of the Santa Elena ophiolite. Liquid Lines of Descent (LLD) were calculated using Petrolog3 (Danyushevsky and Plechov, 2011) at different pressures (1.0 atm to $1.0 \mathrm{GPa}$ in increments of $0.2 \mathrm{GPa}$ ). The crystallization processes modeled start at a primary magma (PM) that has been modified from the EPR composition of Herzberg and O'hara (2002) in order to explain our data. For the fast spreading ridges we used values from the East Pacific Rise (EPR); for slow spreading ridges we used values from slow segments of the Mid-Atlantic ridge (MARR) (<60 mm/yr); for ultra-slow spreading ridges we used values from the Southwestern Indian Ridge (SWIR) and Gakkel Ridge (GAK); for back arc basins we used values from Marianas (BMRN), Lau Basin (LAU) and Scotia Back Arc (SCO) (data compiled by Gale et al., 2013).

Figure 6. Variation diagrams for $\mathrm{CaO}$ and $\mathrm{MgO}$ at different initial compositions. LLDs were modeled for pressures from 0.001 GPa (1atm) to 1.0 GPa using Petrolog3 (Danyushevsky and Plechov, 2011). Panels A and B show experimental glass compositions for pressures at 1 atm, $0.2 \mathrm{GPa}, 0.8 \mathrm{GPa}$ and $1 \mathrm{GPa}$. The experimental glass data collected by different authors was compiled by Herzberg (2004) and includes data from: Bender et al. (1978); Walker et al. (1979), Grove et al. (1982); Grove and Bryan 
(1983); Kinzler and Grove (1985); Mahood and Baker (1986); Baker and Eggler (1987); Falloon and Green (1987); Tormey et al. (1987); Juster et al. (1989); Ussler III and Glazner (1989); Bartels et al. (1991); Thy and Lofgren (1992); Grove et al. (1993); Thy and Lofgren (1994); Yang et al. (1996). We also compiled data from Falloon et al. (2001); Villiger et al. (2004); Villiger et al. (2007); and Falloon et al. (2008). The experimental data was plotted against the LLDs generated for a primary magma from the East Pacific Rise (EPR) calculated by Herzberg and O'Hara (2002) with 0 wt\% $\mathrm{H}_{2} \mathrm{O}$ added (A) and for the same primary EPR magma containing 0.5 wt\% $\mathrm{H}_{2} \mathrm{O}(\mathrm{B})$. Note how the experimental data consistently plots in the appropriate LLD for each value. Also, it should be note how adding $\mathrm{H}_{2} \mathrm{O}$ in these two model causes an upward displacement in the cotectic points. Panels C and D show the data collected in this work using the same LLDs as in A and B, respectively. It should be noted that neither of the two models seem to appropriately describe the trends in the diabase dikes, however, the model with $0.5 \mathrm{wt} \% \mathrm{H}_{2} \mathrm{O}$ added has the best correlation of the two models. Panel E shows the diabase dike compositions with the LLDs generated based on the optimized crystallization model for our data. The model parameters used to generate the LLDs are shown in the inset. The resulting model shows a displacement towards lower $\mathrm{CaO}$ and lower MgO providing a better fit for the diabase samples, where the majority of our samples fall in the LLDs for pressures $>0.4 \mathrm{GPa}$.

Figure 7. Multi-element diagram showing the incompatible element compositions for the Santa Elena Ophiolite diabase dikes and Murcielago Islands pillow basalt glasses normalized to primitive mantle (McDonough and Sun, 1995). Shaded fields represent the values compiled by Gale et al. (2013) from different types of spreading centers. A) Comparison of the Santa Elena diabases and standard values of NMORB, EMORB and OIB (Sun and McDonough, 1989). B) The dark gray shaded area represents values of fast spreading ridges from the East Pacific Rise (EPR). C) The gray area represents values from ultra-slow spreading ridges form Gakkel ridge (GAK) and Southwestern Indian ridge (SWIR). 
Values for slow spreading segments of the Mid-Atlantic ridge (MARR) are represented as a dotted line. D) The light gray shaded area are values from Marianas (BMRN), Lau (LAU) and Scotia (SCO) back-arc basins. E) Samples from the Santa Elena Ophiolite melt-focusing zone compared to the Murcielago Islands basaltic glasses. Note that the Murcielago Islands basaltic glasses share a more similar geochemical signature with the Nicoya peninsula basaltic glasses related to the CLIP. Samples that showed significant spikes in fluid mobile elements were excluded from this figure since seafloor alteration can be accounted for these enrichments.

Figure 8. Tectonic environment discrimination diagrams of Santa Elena Ophiolite and Murcielago Islands samples compared to other ophiolites or oceanic environments. A) and B) $\mathrm{Zr} / \mathrm{Nb}$ vs. Ti/Th diagram. Lower $\mathrm{Ti} / \mathrm{Th}$ and higher $\mathrm{Zr} / \mathrm{Nb}$ indicate increasing subduction fluid interaction. $\mathrm{C}$ ) and $\mathrm{D}$ ) $\mathrm{Ce} / \mathrm{Nb}$ vs. Th/Nb diagram. Subduction influenced samples plot towards higher $\mathrm{Ce}$ and higher Th. Ce can be considered as a proxy for $\mathrm{H}_{2} \mathrm{O}$ content, since both elements have a similar incompatible behavior during melting (Saunders et al., 1988). E) and F) Th/Yb vs. Nb/Yb diagram. Th/Nb is a well-known proxy for subduction input within a system as Th is mobile in fluids and $\mathrm{Nb}$ is retained by a residual phase in the subducting slab (Pearce, 2008). We compiled the most recent geochemical data for similar tholeiitic magmas related to ophiolites: Oman, Newfoundland, Josephine, Mirdita, Macquarie Island, Ingalls, Tangihua, Shuanggou, Kizildag, Anatolia and Troodos, Mayarí-Baracoa Ophiolitic Belt, Loma La Monja, La Desiderade. Information from other analog tectonic environments was also collected: Atlantis Massif in the Mid-Atlantic Ridge, Atlantis Bank in the South West Indian Ridge, the San Souci volcanic formation in Trinidad, contemporaneous Atlantic oceanic crust, Aves Ridge crust, slow (Mid-Atlantic Ridge, MARR) and ultra-slow spreading ridges (Gakkel, GAK and Southwest Indian Ridge, SWIR) and back-arc basins (Marianas, BMRN, Lau Basin, LAU, and Scotia Basin, SCO). Note that the diabase dike samples plot in the 
transition between a MORB environment and a SSZ environment. See Table TS3 in the Supplementary Materials, for data references.

Figure 9. Results from the radiogenic isotope analyses. Values were corrected to the initial ratios and projected considering the evolution of the source at $121 \mathrm{Ma}$. A) $\varepsilon N d$ vs ${ }^{87} \mathrm{Sr} /{ }^{86} \mathrm{Sr}$. B) ${ }^{206} \mathrm{~Pb} /{ }^{204} \mathrm{~Pb}$ vs ${ }^{87} \mathrm{Sr} /{ }^{86} \mathrm{Sr}$. C) ${ }^{207} \mathrm{~Pb} /{ }^{204} \mathrm{~Pb}$ vs ${ }^{206} \mathrm{~Pb} /{ }^{204} \mathrm{~Pb}$. Santa Elena Diabase dikes data show a mixing trend between DMM and EMII. D) ${ }^{208} \mathrm{~Pb} /{ }^{204} \mathrm{~Pb}$ vs ${ }^{206} \mathrm{~Pb} /{ }^{204} \mathrm{~Pb}$. The linearity of the data points also denotes the mixing of DMM and EMII. Note that the isotope signatures of the Santa Elena diabases show similarities with data from slow spreading ridges (Mid-Atlantic ridge, MARR), ultra-slow spreading ridges (Gakkel, GAK and Southwest Indian Ridge, SWIR) and Back Arc Basins, and separates from fast spreading ridges (East Pacific Rise, EPR). Data from Gale et al. (2013). DMM: Depleted MORB Mantle; EMI: Enriched Mantle I; EMII: Enriched Mantle II. Note that samples SE-060111-15 and SE-010510-1 were not included in Fig. 8 a and $b$, given that they show the effect of seafloor alteration.

Figure 10. Location of the Godzilla Megamullion in the Parece Vela Basin, Marianas back-arc (Loocke et al., 2013). A similar geotectonic scenario is proposed for the formation of the Santa Elena Ophiolite. The architectural and geochemical affinities of oceanic core complexes are in good agreement with the evidences found for the Santa Elena Ophiolite. Map obtained from GeoMapApp (http://www.geomapapp.org). B) Schematic section of an OCC, modified from Karson et al. (2006). C) Schematic cross section of Santa Elena Ophiolite. 


\section{References}

Acocella, V. and Neri, M., 2009. Dike propagation in volcanic edifices: Overview and possible developments. Tectonophysics, 471(1-2): 67-77.

Ancochea, E., Brändle, J.L., Huertas, M.J., Hernán, F. and Herrera, R., 2008. Dike-swarms, key to reconstruction of major volcanic edifices: The basic dikes of La Gomera (Canary Islands). Journal of Volcanology and Geothermal research, 173: 207-216.

Arias, M., 2002. Petrografía y geoquímica de las rocas del Complejo Ígneo Estratificado de Bahía Nancite y su relación con los filones basálticos, península de Santa Elena, Costa Rica, Universidad de Costa Rica, San José, Costa Rica, 90 pp.

Asimow, P.D. and Langmuir, C., 2003. The importance of water to oceanic mantle melting regimes. Nature, 421(6925): 815-820.

Baines, A.G., Cheadle, M.J., Dick, H.J.B., Scheirer, A.H., John, B.E., Kusznir, N.J. and Matsumoto, T., 2003. Mechanism for generating the anomalous uplift of oceanic core complexes: Atlantis Bank, southwest Indian Ridge. Geology, 31(12): 1105-1108.

Baker, D.R. and Eggler, D.H., 1987. Compositions of anhydrous and hydrous melts coexisting with plagioclase, augite, and olivine or low-Ca pyroxene from $1 \mathrm{~atm}$ to $8 \mathrm{kbar}$; application to the Aleutian volcanic center of Atka. American Mineralogist, 72(1-2): 12-28.

Bandini, A., Baumgartner, P., Flores, K., Dumitrica, P., Hochard, C., Stampfli, G. and Jackett, S.-J., 2011. Aalenian to Cenomanian Radiolaria of the Bermeja Complex (Puerto Rico) and Pacific origin of radiolarites on the Caribbean Plate. Swiss Journal of Geosciences, 104(3): 367-408.

Bartels, K.S., Kinzler, R.J. and Grove, T.L., 1991. High pressure phase relations of primitive high-alumina basalts from Medicine Lake volcano, northern California. Contributions to Mineralogy and Petrology, 108(3): 253-270.

Baumgartner, P. and Denyer, P., 2006. Evidende for middle Cretaceous accretion at Santa Elena Peninsula (Santa Rosa Accretionary Complex), Costa Rica. Geologica Acta, 4(1-2): 179-191.

Baumgartner, P., Flores, K., Bandini, A., Girault, F. and Cruz, D., 2008. Upper Triassic to Cretaceous radiolaria from Nicaragua and northern Costa Rica: The Mesquito composite oceanic terrane. Ofioliti, 33(1): 1-19.

Beccaluva, L., Chinchilla-Cháves, A.L., Coltorti, M., Giunta, G., Siena, F. and Vaccaro, C., 1999. Petrological and structural significance of the Santa Elena-Nicoya Ophiolitic Complex in Costa Rica and geodynamic implications. European Journal of Mineralogy, 11: 1091-1107.

Bender, J., Hodges, F. and Bence, A., 1978. Petrogenesis of basalts from the project FAMOUS area: experimental study from 0 to 15 kbars. Earth and Planetary Science Letters, 41(3): 277-302.

Blackman, D., Karson, J., Kelley, D., Cann, J., Früh-Green, G., Gee, J., Hurst, S., John, B., Morgan, J., Nooner, S., Ross, D.K., Schroeder, T. and Williams, E., 2002. Geology of the Atlantis Massif (MidAtlantic Ridge, $\left.30^{\circ} \mathrm{N}\right)$ : Implications for the evolution of an ultramafic oceanic core complex. Marine Geophysical Researches, 23(5-6): 443-469.

Boudier, F., Ceuleneer, G. and Nicolas, A., 1988. Shear zones, thrusts and related magmatism in the Oman ophiolite: initiation of thrusting on an oceanic ridge. Tectonophysics, 151: 275-296.

Boudier, F. and Nicolas, A., 1985. Harzburgite and Iherzolite subtypes in ophiolitic and oceanic environments. Earth and Planetary Science Letters, 76: 84-92.

Bouilhol, P., Connolly, J.A.D. and Burg, J.-P., 2011. Geological evidence and modeling of melt migration by porosity waves in the sub-arc mantle of Kohistan (Pakistan). Geology, 39(12): 1091-1094.

Buchs, D.M., Pilet, S., Cosca, M., Flores, K.E., Bandini, A.N. and Baumgartner, P.O., 2013. Low-volume intraplate volcanism in the Early/Middle Jurassic Pacific basin documented by accreted sequences in Costa Rica. Geochemistry, Geophysics, Geosystems, 14(5): 1552-1568. 
Cann, J.R., 1970. Rb, Sr, Y, Zr and $\mathrm{Nb}$ in some ocean floor basaltic rocks. Earth and Planetary Science Letters, 10(1): 7-11.

Cannat, M., 1996. How thick is the magmatic crust at slow spreading oceanic ridges? Journal of Geophysical Research, 101(B2): 2847-2857.

Cannat, M., Manatschal, G., Sauter, D. and Péron-Pinvidic, G., 2009. Assessing the conditions of continental breakup at magma-poor rifted margins: What can we learn from slow spreading mid-ocean ridges? Comptes Rendus Geoscience, 341(5): 406-427.

Cannat, M., Sauter, D., Mendel, V., Ruellan, E., Okino, K., Escartin, J., Combier, V. and Baala, M., 2006. Modes of seafloor generation at a melt-poor ultraslow-spreading ridge. Geology, 34(7): 605-608.

Coleman, D.S., Gray, W. and Glazner, A.F., 2004. Rethinking the emplacement and evolution of zoned plutons: Geochronologic evidence for incremental assembly of the Tuolumne Intrusive Suite, California. Geology, 32(5): 433-436.

Coleman, R.G., 1971. Plate tectonic emplacement of Upper Mantle Peridotites along continental edges. Journal of Geophysical Research, 76(5): 1212-1222.

Danyushevsky, L.V., 2001. The effect of small amounts of $\mathrm{H} 2 \mathrm{O}$ on crystallisation of mid-ocean ridge and backarc basin magmas. Journal of Volcanology and Geothermal Research, 110(3-4): 265-280.

Danyushevsky, L.V. and Plechov, P., 2011. Petrolog3: Integrated software for modeling crystallization processes. Geochemistry, Geophysics, Geosystems, 12(7): Q07021.

Dasgupta, R. and Hirschmann, M.M., 2006. Melting in the Earth's deep upper mantle caused by carbon dioxide. Nature, 440(7084): 659-662.

Delvaux, D. and Sperner, B., 2003. New aspects of tectonic stress inversion with reference to the TENSOR program. Geological Society, London, Special Publications, 212(1): 75-100.

DeMets, C., 2001. A new estimate for present-day Cocos-Caribbean plate motion: Implications for slip along the Central American volcanic arc. Geophysical Research Letters, 28(21): 4043-4046.

Dengo, G., 1962. Tectonic-igenuos sequence in Costa Rica In: Engel, A. E. J., James, H. J., Leonard, B. F. (Eds.), A volume to honor A. F. Budington. Geological Society of America Special Volume: pp. 133-161.

Denyer, P., Baumgartner, P. and Gazel, E., 2006. Characterization and tectonic implications of MesozoicCenozoic oceanic assemblages of Costa Rica and Western Panama. Geologica Acta, 4(1-2): 219235.

Denyer, P. and Gazel, E., 2009. The Costa Rican Jurassic to Miocen oceanic complexes: Origin, tectonics and relations. Journal of South American Earth Sciences, 28: 429-442.

Dewey, J.F., 1976. Ophiolite obduction Tectonophysics, 31: 93-120.

Dewey, J.F. and Bird, J.M., 1971. Origin and emplacement of the Ophiolite Suite: Appalachian Ophiolites in Newfoundland. Journal of Geophysical Research, 76(14): 3179-3206.

Dewey, J.F. and Casey, J.F., 2011. The Origin of Obducted Large-Slab Ophiolite Complexes, Arc-Continent Collision. Frontiers in Earth Sciences. Springer Berlin Heidelberg, pp. 431-444.

Dick, H.J.B., Lin, J. and Schouten, H., 2003. An ultraslow-spreading class of ocean ridge. Nature, 426: 405412.

Dick, H.J.B., Tivey, M.A. and Tucholke, B.E., 2008. Plutonic foundation of a slow-spreading ridge segment: Oceanic core complex at Kane Megamullion, $23^{\circ} 30^{\prime} \mathrm{N}, 45^{\circ} 20^{\prime} \mathrm{W}$. Geochemistry, Geophysics, Geosystems, 9(5): Q05014.

Dilek, Y. and Furnes, H., 2009. Structure and geochemistry of Tethyan ophiolites and their petrogenesis in subduction rollback systems. Lithos, 113(1-2): 1-20.

Dilek, Y. and Furnes, H., 2011. Ophiolite genesis and global tectonics: Geochemical and tectonic fingerprinting of ancient oceanic lithosphere. Geological Society of America Bulletin, 123(3-4): 387-411.

Dilek, Y. and Furnes, H., 2014. Ophiolites and Their Origins. Elements, 10(2): 93-100. 
Eggins, S.M., Rudnick, R.L. and McDonough, W.F., 1998. The composition of peridotites and their minerals: a laser-ablation ICP-MS study. Earth and Planetary Science Letters, 154(1-4): 53-71.

Escartín, J., Mével, C., MacLeod, C.J. and McCaig, A.M., 2003. Constraints on deformation conditions and the origin of oceanic detachments: The Mid-Atlantic Ridge core complex at $15^{\circ} 45^{\prime} \mathrm{N}$. Geochemistry, Geophysics, Geosystems, 4(8): 1067.

Escartin, J., Smith, D.K., Cann, J., Schouten, H., Langmuir, C.H. and Escrig, S., 2008. Central role of detachment faults in accretion of slow-spreading oceanic lithosphere. Nature, 455(7214): $790-$ 794.

Escuder-Viruete, J. and Baumgartner, P.O., 2014. Structural evolution and deformation kinematics of a subduction-related serpentinite-matrix mélange, Santa Elena Peninsula, northwest Costa Rica. Journal of Structural Geology(0).

Escuder-Viruete, J., Pérez-Estaún, A. and Weis, D., 2009. Geochemical constraints on the origin of the late Jurassic proto-Caribbean oceanic crust in Hispaniola. International Journal of Earth Sciences, 98(2): 407-425.

Falloon, T. and Green, D., 1987. Anhydrous partial melting of MORB pyrolite and other peridotite compositions at $10 \mathrm{kbar}$ : implications for the origin of primitive MORB glasses. Mineralogy and Petrology, 37(3-4): 181-219.

Falloon, T.J., Danyushevsky, L.V. and Green, D.H., 2001. Peridotite Melting at 1 GPa: Reversal Experiments on Partial Melt Compositions Produced by Peridotite-Basalt Sandwich Experiments. Journal of Petrology, 42(12): 2363-2390.

Falloon, T.J., Green, D.H., Danyushevsky, L.V. and McNeill, A.W., 2008. The Composition of Near-solidus Partial Melts of Fertile Peridotite at 1 and $1.5 \mathrm{GPa}$ : Implications for the Petrogenesis of MORB. Journal of Petrology, 49(4): 591-613.

Faul, U.H., 2001. Melt retention and segregation beneath mid-ocean ridges. Nature, 410(6831): 920-923.

Floyd, P.A. and Winchester, J.A., 1975. Magma type and tectonic setting discrimination using immobile elements. Earth and Planetary Science Letters, 27(2): 211-218.

Gale, A., Dalton, C.A., Langmuir, C.H., Su, Y. and Schilling, J.-G., 2013. The mean composition of ocean ridge basalts. Geochemistry Geophysics Geosystems, 14(3): 489-518.

Gazel, E., Denyer, P. and Baumgartner, P., 2006. Magmatic and geotectonic significance of Santa Elena Peninsula, Costa Rica. Geologica Acta, 4(1-2): 193-202.

Gazel, E., Plank, T., Forsyth, D.W., Bendersky, C., Lee, C.-T.A. and Hauri, E.H., 2012. Lithosphere versus asthenosphere mantle sources at the Big Pine Volcanic Field, California. Geochemistry, Geophysics, Geosystems, 13(6): Q0AK06.

Geldmacher, J., Hoernle, K., van den Bogaard, P., Hauff, F. and Klügel, A., 2008. Age and Geochemistry of the Central American Forearc Basement (DSDP Leg 67 and 84): Insights into Mezosoic Arc Volcanism and Seamount Accretion on the Fringe of the Caribbean LIP. Journal of Petrology, 49(10): 1781-1815.

Godard, M., Jousselin, D. and Bodinier, J.-L., 2000. Relationships between geochemistry and structure beneath a palaeo-spreading centre: a study of the mantle section in the Oman ophiolite. Earth and Planetary Science Letters, 180(1-2): 133-148.

Godard, M., Lagabrielle, Y., Alard, O. and Harvey, J., 2008. Geochemistry of the highly depleted peridotites drilled at ODP Sites 1272 and 1274 (Fifteen-Twenty Fracture Zone, Mid-Atlantic Ridge): Implications for mantle dynamics beneath a slow spreading ridge. Earth and Planetary Science Letters, 267: 410-425.

Gray, W., Glazner, A.F., Coleman, D.S. and Bartley, J.M., 2008. Long-term geochemical variability of the Late Cretaceous Tuolumne Intrusive Suite, central Sierra Nevada, California. Geological Society, London, Special Publications, 304(1): 183-201. 
Grove, T.L. and Bryan, W., 1983. Fractionation of pyroxene-phyric MORB at low pressure: an experimental study. Contributions to Mineralogy and Petrology, 84(4): 293-309.

Grove, T.L., Gerlach, D.C. and Sando, T.W., 1982. Origin of calc-alkaline series lavas at Medicine Lake volcano by fractionation, assimilation and mixing. Contributions to Mineralogy and Petrology, 80(2): 160-182.

Grove, T.L., Kinzler, R.J. and Bryan, W.B., 1993. Fractionation of mid-ocean ridge basalt (MORB). Mantle flow and melt generation at mid-ocean ridges: 281-310.

Gudmundsson, A., 1990a. Dyke emplacement at divergent plate boundaries. In: A.J. Parker, P.C. Rickwood and D.H. Tucker (Editors), Mafic Dykes and Emplacement Mechanisms, Balkema, Rotterdam, pp. 47-62.

Gudmundsson, A., 1990b. Emplacement of dikes, sills and crustal magma chambers at divergent plate boundaries. Tectonophysics, 176(3-4): 257-275.

Gudmundsson, A., 2011. Deflection of dykes into sills at discontinuities and magma-chamber formation. Tectonophysics, 500(1-4): 50-64.

Hauff, F., Hoernle, K., Schmincke, H.-U. and Werner, R., 1997. A Mid Cretaceous origin for the Galápagos hotspot: volcanological, petrologica and geochemical evidence from Costa Rican oceanic crustal segments. Geologische Rundschau, 86(1): 141-155.

Hauff, F., Hoernle, K., van den Bogaard, P., Alvarado, G. and Garbe-Schönberg, D., 2000. Age and geochemistry of basaltic complexes in western Costa Rica: Contributions to the geotectonic evolution of Central America. Geochemistry Geophysics Geosystems, 1.

Herzberg, C., 2004. Partial Crystallization of Mid-Ocean Ridge Basalts in the Crust and Mantle. Journal of Petrology, 45(12): 2389-2405.

Herzberg, C. and Gazel, E., 2009. Petrological evidence for secular cooling in mantle plumes. Nature, 458(7238): 619-622.

Herzberg, C. and O'Hara, M.J., 1998. Phase equilibrium constraints on the origin of basalts, picrites, and komatiites. Earth-Science Reviews, 44(1-2): 39-79.

Herzberg, C. and O'Hara, M.J., 2002. Plume-Associated Ultramafic Magmas of Phanerozoic Age. Journal of Petrology, 43(10): 1857-1883.

Hirth, G. and Kohlstedt, D.L., 1996. Water in the oceanic upper mantle: implications for rheology, melt extraction and the evolution of the lithosphere. Earth and Planetary Science Letters, 144(1-2): 93-108.

Hoernle, K., Hauff, F. and van den Bogaard, P., 2004. 70 m.y. history (136-69 Ma) for the Caribbean Large Igneous Province. Geological Society of America, 32(8): 697-700.

Irvine, T. and Baragar, W., 1971. A guide to the chemical classification of the common volcanic rocks. Canadian journal of earth sciences, 8(5): 523-548.

Ishiwatari, A., 1985. Alpine ophiolites: product of low-degree mantle melting in a Mesozoic transcurrent rift zone. Earth and Planetary Science Letters, 76: 93-108.

Jackson, E. and Thayer, T., 1972. Some criteria for distinguishing between stratiform, concentric and alpine peridotite-gabbro complexes. Proc. 24th Internat. Geol. Congr, 2: 289-296.

Jokat, W., Ritzmann, O., Schmidt-Aursch, M.C., Drachev, S., Gauger, S. and Snow, J., 2003. Geophysical evidence for reduced melt production on the Arctic ultraslow Gakkel mid-ocean ridge. Nature, 423(6943): 962-965.

Juster, T.C., Grove, T.L. and Perfit, M.R., 1989. Experimental constraints on the generation of FeTi basalts, andesites, and rhyodacites at the Galapagos Spreading Center, $85 \mathrm{~W}$ and $95 \mathrm{~W}$. Journal of Geophysical Research: Solid Earth (1978-2012), 94(B7): 9251-9274.

Karato, S.-i. and Jung, H., 1998. Water, partial melting and the origin of the seismic low velocity and high attenuation zone in the upper mantle. Earth and Planetary Science Letters, 157(3-4): 193-207. 
Karson, J.A., Früh-Green, G.L., Kelley, D.S., Williams, E.A., Yoerger, D.R. and Jakuba, M., 2006. Detachment shear zone of the Atlantis Massif core complex, Mid-Atlantic Ridge, $30^{\circ} \mathrm{N}$. Geochemistry, Geophysics, Geosystems, 7(6): Q06016.

Kelemen, P.B., Braun, M. and Hirth, G., 2000. Spatial distribution of melt conduits in the mantle beneath oceanic spreading ridges: Observations from the Ingalls and Oman ophiolites. Geochemistry, Geophysics, Geosystems, 1(7): 1005.

Kelemen, P.B., Hirth, G., Shimizu, N., Spiegelman, M. and Dick, H.J., 1997. A review of melt migration processes in the adiabatically upwelling mantle beneath oceanic spreading ridges. Philosophical Transactions of the Royal Society of London. Series A: Mathematical, Physical and Engineering Sciences, 355(1723): 283-318.

Kelemen, P.B., Yogodzinski, G.M. and Scholl, D.W., 2003. Along-Strike Variation in the Aleutian Island Arc: Genesis of High Mg\# Andesite and Implications for Continental Crust. Inside the subduction factory: 223-276.

Kinzler, R.J. and Grove, T.L., 1985. Crystallization and differentiation of Archean komatiite lavas from Northeast Ontario; phase equilibrium and kinetic studies. American Mineralogist, 70(1-2): 40-51.

Kress, V.C. and Carmichael, I.S.E., 1988. Stoichiometry of the iron oxidation reaction in silicate melts. American Mineralogist, 73: 1267-1274.

Kuiper, K.F., Deino, A., Hilgen, F.J., Krijgsman, W., Renne, P.R. and Wijbrans, J.R., 2008. Synchronizing Rock Clocks of Earth History. Science, 320(5875): 500-504.

Kussmaul, S., Paniagua, S. and Gainza, J., 1982. Recopilación, clasificación e interpretación petroquímica de las rocas ígneas de Costa Rica. Instituto Geográfico Nacional Informe Semestral juliodiciembre, 28: 17-79.

Lagabrielle, Y., Vitale Brovarone, A. and Ildefonse, B., 2015. Fossil oceanic core complexes recognized in the blueschist metaophiolites of Western Alps and Corsica. Earth-Science Reviews, 141(0): 1-26.

Langmuir, C.H., Klein, E.M. and Plank, T., 1992. Petrological systematics of mid-ocean ridge basalts: Constraints on melt generation beneath ocean ridges. Geophysical Monograph Series, 71: 183280.

Lapierre, H., Dupuis, V., Lépinay, B.M.d., Bosch, D., Monié, P., Tardy, M., Maury, R.C., Hernandez, J., Polvé, M., Yeghicheyan, D. and Cotten, J., 1999. Late Jurassic Oceanic Crust and Upper Cretaceous Caribbean Plateau Picritic Basalts Exposed in the Duarte Igneous Complex, Hispaniola. The Journal of Geology, 107(2): 193-207.

Le Maitre, R.W., Bateman, P., Dudek, A., Keller, J., Lameyre, J., Le Bas, M., Sabine, P., Schmid, R., Sorensen, H. and Streckeisen, A., 1989. A classification of igneous rocks and glossary of terms: Recommendations of the International Union of Geological Sciences Subcommission on the Systematics of Igneous Rocks, 193. Blackwell Oxford.

Loocke, M., Snow, J.E. and Ohara, Y., 2013. Melt stagnation in peridotites from the Godzilla Megamullion Oceanic Core Complex, Parece Vela Basin, Philippine Sea. Lithos, 182-183(0): 1-10.

Maccaferri, F., Bonafede, M. and Rivalta, E., 2011. A quantitative study of the mechanisms governing dike propagation, dike arrest and sill formation. Journal of Volcanology and Geothermal Research, 208(1-2): 39-50.

Macdonald, K.C., 1982. Mid-ocean ridges: Fine scale tectonic, volcanic and hydrothermal processes within the plate boundary zone. Annual Review of Earth and Planetary Sciences, 10: 155.

Mahood, G.A. and Baker, D.R., 1986. Experimental constraints on depths of fractionation of mildly alkalic basalts and associated felsic rocks: Pantelleria, Strait of Sicily. Contributions to Mineralogy and Petrology, 93(2): 251-264.

Manatschal, G., Sauter, D., Karpoff, A.M., Masini, E., Mohn, G. and Lagabrielle, Y., 2011. The Chenaillet Ophiolite in the French/Italian Alps: An ancient analogue for an Oceanic Core Complex? Lithos, 124(3-4): 169-184. 
Marchesi, C., Garrido, C., Godard, M., Proenza, J., Gervilla, F. and Blanco-Moreno, J., 2006. Petrogenesis of highly depleted peridotites and gabbroic rocks from the Mayarí-Baracoa Ophiolitic Belt (eastern Cuba). Contributions to Mineralogy and Petrology, 151(6): 717-736.

McDonough, W.F. and Sun, S.s., 1995. The composition of the Earth. Chemical Geology, 120(3-4): 223253.

Meschede, M. and Frisch, W., 1994. Geochemical characteristics of basaltic rocks from the Central American ophiolites. Profil, 7: 71-85.

Meschede, M. and Wolfgang, F., 1998. A plate-tectonic model for the Mesozoic and Early Cenozoic history of the Caribbean plate. Tectonophysics, 296: 269-291.

Michael, P.J. and Cornell, W.C., 1998. Influence of spreading rate and magma supply on crystallization and assimilation beneath mid-ocean ridges: Evidence from chlorine and major element chemistry of mid-ocean ridge basalts. Journal of Geophysical Research: Solid Earth, 103(B8): 18325-18356.

Michael, P.J., Langmuir, C.H., Dick, H.J.B., Snow, J.E., Goldstein, S.L., Graham, D.W., Lehnert, K., Kurras, G., Jokat, W., Mühe, R. and Edmonds, H.N., 2003. Magmatic and amagmatic seafloor generation at the ultraslow-spreading Gakkel ridge, Artic Ocean. Nature, 423: 956-961.

Min, K., Mundil, R., Renne, P.R. and Ludwig, K.R., 2000. A test for systematic errors in 40Ar/39Ar geochronology through comparison with $\mathrm{U} / \mathrm{Pb}$ analysis of a 1.1-Ga rhyolite. Geochimica et Cosmochimica Acta, 64(1): 73-98.

Neill, I., Kerr, A.C., Chamberlain, K.R., Schmitt, A.K., Urbani, F., Hastie, A.R., Pindell, J.L., Barry, T.L. and Millar, I.L., 2014. Vestiges of the proto-Caribbean seaway: Origin of the San Souci Volcanic Group, Trinidad. Tectonophysics, 626(0): 170-185.

Nicolas, A. and Boudier, F., 2003. Where ophiolites come from and what they tell us. In: Y. Dilek and S. Newcomb (Editors), Ophiolite concept and the evolution of geological thought. Geological Society of America Special Paper 373, Boulder, Colorado, pp. 137-152.

Nicolas, A., Boudier, F. and Meshi, A., 1999. Slow spreading accretion and mantle denudation in the Mirdita ophiolite (Albania). Journal of Geophysical Research: Solid Earth, 104(B7): 15155-15167.

Norrish, K. and Hutton, J.T., 1969. An accurate X-ray spectrographic method for the analysis of a wide range of geological samples. Geochimica et Cosmochimica Acta, 33(4): 431-453.

O'Hara, M.J., 1985. Importance of the 'shape' of the melting regime during partial melting of the mantle. Nature, 314(6006): 58-62.

Ohara, Y., Fujioka, K., Ishii, T. and Yurimoto, H., 2003. Peridotites and gabbros from the Parece Vela backarc basin: Unique tectonic window in an extinct backarc spreading ridge. Geochemistry, Geophysics, Geosystems, 4(7): 8611.

Ohara, Y., Yoshida, T., Kato, Y. and Kasuga, S., 2001. Giant Megamullion in the Parece Vela Backarc Basin. Marine Geophysical Researches, 22(1): 47-61.

Paquet, F., Dauteuil, O., Hallot, E. and Moreau, F., 2007. Tectonics and magma dynamics coupling in a dyke swarm of Iceland. Journal of Structural Geology, 29: 1477-1493.

Pearce, J.A., 1975. Basalt geochemistry used to investigate past tectonic environments on Cyprus. Tectonophysics, 25(1-2): 41-67.

Pearce, J.A., 2008. Geochemical fingerprinting of oceanic basalts with applications to ophiolite classification and the search for Archean oceanic crust. Lithos, 100: 14-48.

Pearce, J.A., 2014. Immobile Element Fingerprinting of Ophiolites. Elements, 10(2): 101-108.

Pearce, J.A. and Cann, J.R., 1971. Ophiolite origin investigated by discriminant analysis using $\mathrm{Ti}, \mathrm{Zr}$ and $\mathrm{Y}$. Earth and Planetary Science Letters, 12(3): 339-349.

Ragazzi, C., 1996. Petrologia e geologia del Complesso Ofiolitico di Nicoya-St. Elena (Costa Rica). Università degli Studi di Ferrara, 115 pp. 
Robinson, P.T., Malpas, J., Dilek, Y. and Zhou, M., 2008. The significance of sheeted dike complexes in ophiolites. GSA Today, 18(11): 4-10.

Saginor, I., Gazel, E., Carr, M.J., Swisher, C.C. and Turrin, B., 2011. New Pliocene-Pleistocene $40 \mathrm{Ar} / 39 \mathrm{Ar}$ ages fill in temporal gaps in the Nicaraguan volcanic record. Journal of Volcanology and Geothermal Research, 202(1): 143-152.

Saginor, I., Gazel, E., Condie, C. and Carr, M.J., 2013. Evolution of geochemical variations along the Central American volcanic front. Geochemistry, Geophysics, Geosystems, 14(10): 4504-4522.

Salters, V.J.M. and Stracke, A., 2004. Composition of the depleted mantle. Geochemistry, Geophysics, Geosystems, 5(5): Q05B07.

Samuel, H. and King, S.D., 2014. Mixing at mid-ocean ridges controlled by small-scale convection and plate motion. Nature Geosci, 7(8): 602-605.

Sanfilippo, A., Dick, H.J.B. and Ohara, Y., 2013. Melt-Rock Reaction in the Mantle: Mantle Troctolites from the Parece Vela Ancient Back-Arc Spreading Center. Journal of Petrology, 54(5): 861-885.

Saunders, A.D., Norry, M.J. and Tarney, J., 1988. Origin of MORB and Chemically-Depleted Mantle Reservoirs: Trace Element Constraints. Journal of Petrology, Special_Volume(1): 415-445.

Sauter, D., Sloan, H., Cannat, M., Goff, J., Patriat, P., Schaming, M. and Roest, W.R., 2011. From slow to ultra-slow: How does spreading rate affect seafloor roughness and crustal thickness? Geology, 39(10): 911-914.

Shaw, D.M., 1970. Trace element fractionation during anatexis. Geochimica et Cosmochimica Acta, 34(2): 237-243.

Shervais, J.W., 1982. Ti-V plots and the petrogenesis of modern and ophiolitic lavas. Earth and Planetary Science Letters, 59(1): 101-118.

Sinton, C.W., Duncan, R.A. and Denyer, P., 1997. Nicoya Peninsula, Costa Rica: A single suite of Caribbean oceanic plateau magmas. Journal of Geophysical Research: Solid Earth, 102(B7): 15507-15520.

Snow, J.E. and Edmonds, H.N., 2007. Ultraslow-spreading ridges: rapid paradigm changes. OCEANOGRAPHY-WASHINGTON DC-OCEANOGRAPHY SOCIETY-, 20(1): 90.

Spiegelman, M., Kelemen, P.B. and Aharonov, E., 2001. Causes and consequences of flow organization during melt transport: The reaction infiltration instability in compactible media. Journal of Geophysical Research: Solid Earth (1978-2012), 106(B2): 2061-2077.

Staudigel, H., 2003. Hydrothermal alteration processes in the oceanic crust. Treatise on geochemistry, 3 : 511-535.

Staudigel, H., Hart, S.R. and Richardson, S.H., 1981. Alteration of the oceanic crust: Processes and timing. Earth and Planetary Science Letters, 52(2): 311-327.

Staudigel, H., Plank, T., White, B. and Schmincke, H.U., 1996. Geochemical fluxes during seafloor alteration of the basaltic upper oceanic Crust: DSDP sites 417 and 418, Subduction Top to Bottom. Geophys. Monogr. Ser. AGU, Washington, DC, pp. 19-38.

Steinmann, G., Bernoulli, D. and Friedman, G.M., 2003. Die ophiolithischen Zonen in den mediterranen Kettengebirgen (The ophiolitic zones in the Mediterranean mountain chains). SPECIAL PAPERSGEOLOGICAL SOCIETY OF AMERICA: 77-92.

Stewart, M.A., Karson, J.A. and Klein, E.M., 2005. Four-dimensional upper crustal construction at fastspreading mid-ocean ridges: A perspective from an upper crustal cross-section at the Hess Deep Rift. Journal of Volcanology and Geothermal Research, 144(1-4): 287-309.

Sun, S.-s. and McDonough, W.F., 1989. Chemical and isotopic systematics of oceanic basalts: implications for mantle composition and processes. Geological Society, London, Special Publications, 42(1): 313-345. 
Thy, P. and Lofgren, G., 1992. Experimental constraints on the low-pressure evolution of transitional and mildly alkalic basalts: multisaturated liquids and coexisting augites. Contributions to Mineralogy and Petrology, 112(2-3): 196-202.

Thy, P. and Lofgren, G., 1994. Experimental constraints on the low-pressure evolution of transitional and mildly alkalic basalts: the effect of Fe-Ti oxide minerals and the origin of basaltic andesites. Contributions to Mineralogy and Petrology, 116(3): 340-351.

Till, C.B., Grove, T.L. and Krawczynski, M.J., 2012. A melting model for variably depleted and enriched Iherzolite in the plagioclase and spinel stability fields. Journal of Geophysical Research: Solid Earth (1978-2012), 117(B6).

Tormey, D., Grove, T. and Bryan, W., 1987. Experimental petrology of normal MORB near the Kane Fracture Zone: 22-25 N, mid-Atlantic ridge. Contributions to Mineralogy and Petrology, 96(2): 121-139.

Tournon, J., 1984. Magmatismes du mesozoique à l'actuel en Amerique Centrale: L'exemple de Costa Rica, des ophiolites aux andesites.

Tournon, J., 1994. The Santa Elena Peninsula: an ophiolitic nappe and a sedimentary volcanic relative autochthonus. Profil, 7(7): 87-96.

Tournon, J. and Azéma, J., 1980. Sobre la estructura y la petrología del macizo ultrabásico de Santa Elena (Provincia de Guanacaste, Costa Rica). Inst. Geogr. Nacional, Inf. Semestral, 26: 17-54.

Tournon, J. and Bellon, H., 2009. The southern Central America puzzle: cronology and structure a review. Revista Geológica de América Central, 40(40): 11-47.

Tournon, J., Seyler, M. and Astorga, A., 1995. Les périodotites du Rio San Juan (Nicaragua et Costa Rica): jalons possibles d'une suture ultrabasique EW en Amérique Centrale méridionale. Comptes rendus de l'Académie des sciences. Série 2. Sciences de la terre et des planètes, 320(8): 757-764.

Tremblay, A., Meshi, A. and Bédard, J.H., 2009. Oceanic core complexes and ancient oceanic lithosphere: Insights from lapetan and Tethyan ophiolites (Canada and Albania). Tectonophysics, 473(1-2): 36-52.

Ussler III, W. and Glazner, A.F., 1989. Phase equilibria along a basalt-rhyolite mixing line: Implications for the origin of calc-alkaline intermediate magmas. Contributions to Mineralogy and Petrology, 101(2): 232-244.

Veloso, E.E., Hayman, N.W., Anma, R., Tominaga, M., González, R.T., Yamazaki, T. and Astudillo, N., 2014. Magma flow directions in the sheeted dike complex at superfast spreading mid-ocean ridges: Insights from IODP Hole 1256D, Eastern Pacific. Geochemistry, Geophysics, Geosystems, 15(4): 1283-1295.

Villiger, S., Ulmer, P. and Müntener, O., 2007. Equilibrium and Fractional Crystallization Experiments at $0.7 \mathrm{GPa}$; the Effect of Pressure on Phase Relations and Liquid Compositions of Tholeiitic Magmas. Journal of Petrology, 48(1): 159-184.

Villiger, S., Ulmer, P., Müntener, O. and Thompson, A.B., 2004. The Liquid Line of Descent of Anhydrous, Mantle-Derived, Tholeiitic Liquids by Fractional and Equilibrium Crystallization-an Experimental Study at 1.0 GPa. Journal of Petrology, 45(12): 2369-2388.

Walker, D., Shibata, T. and DeLong, S.E., 1979. Abyssal tholeiites from the Oceanographer fracture zone. Contributions to Mineralogy and Petrology, 70(2): 111-125.

Wildberg, H.G.H., 1984. Der Nicoya Komplex, Costa Rica, Zentralamerika: Magmatismus und genese eines polymagmatischen Ophiolith-Komplexes. Münster Forschngsschwerpunkte Geologisch Paläontologisches, 62: 1-123.

Wood, D.A., Joron, J.-L. and Treuil, M., 1979. A re-appraisal of the use of trace elements to classify and discriminate between magma series erupted in different tectonic settings. Earth and Planetary Science Letters, 45(2): 326-336. 
Workman, R.K. and Hart, S.R., 2005. Major and trace element composition of the depleted MORB mantle (DMM). Earth and Planetary Science Letters, 231(1-2): 53-72.

Workman, R.K., Hart, S.R., Jackson, M., Regelous, M., Farley, K.A., Blusztajn, J., Kurz, M. and Staudigel, H., 2004. Recycled metasomatized lithosphere as the origin of the Enriched Mantle II (EM2) endmember: Evidence from the Samoan Volcanic Chain. Geochemistry, Geophysics, Geosystems, 5(4): Q04008.

Yang, H.-J., Kinzler, R.J. and Grove, T., 1996. Experiments and models of anhydrous, basaltic olivineplagioclase-augite saturated melts from 0.001 to $10 \mathrm{kbar}$. Contributions to Mineralogy and Petrology, 124(1): 1-18.

Zimmer, M.M., Plank, T., Hauri, E.H., Yogodzinski, G.M., Stelling, P., Larsen, J., Singer, B., Jicha, B., Mandeville, C. and Nye, C.J., 2010. The Role of Water in Generating the Calc-alkaline Trend: New Volatile Data for Aleutian Magmas and a New Tholeiitic Index. Journal of Petrology, 51(12): 2411-2444. 


\section{Figure 1}

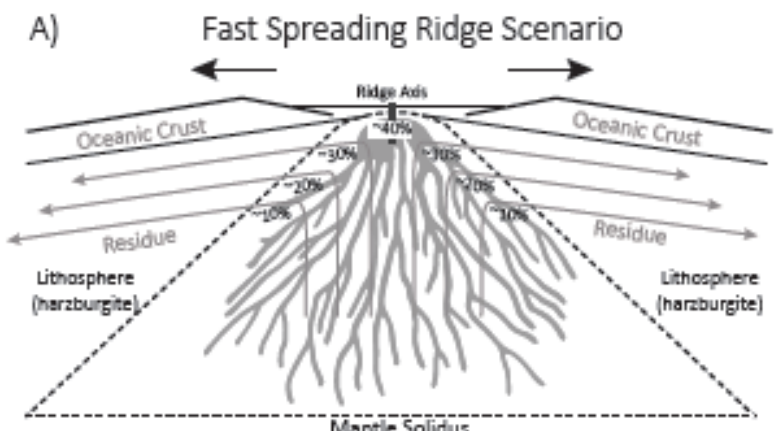

Mantle Solidus

B) Ultra-slow Spreading Ridge Scenario

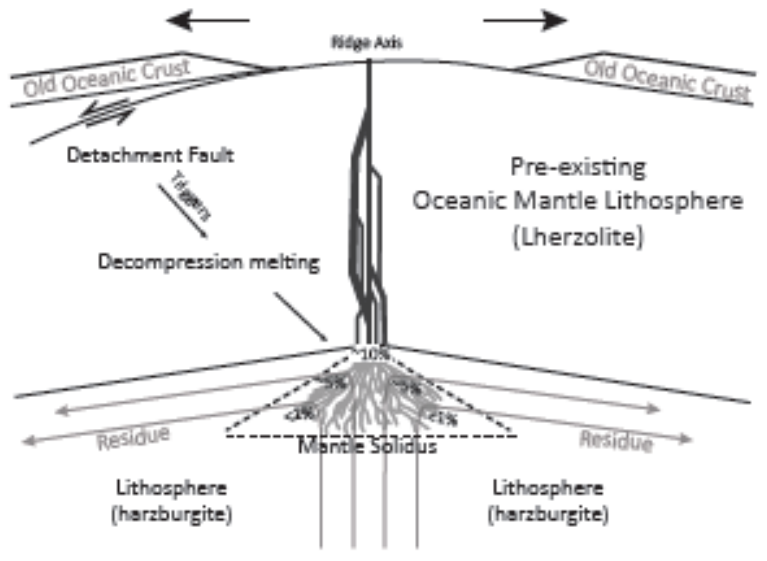




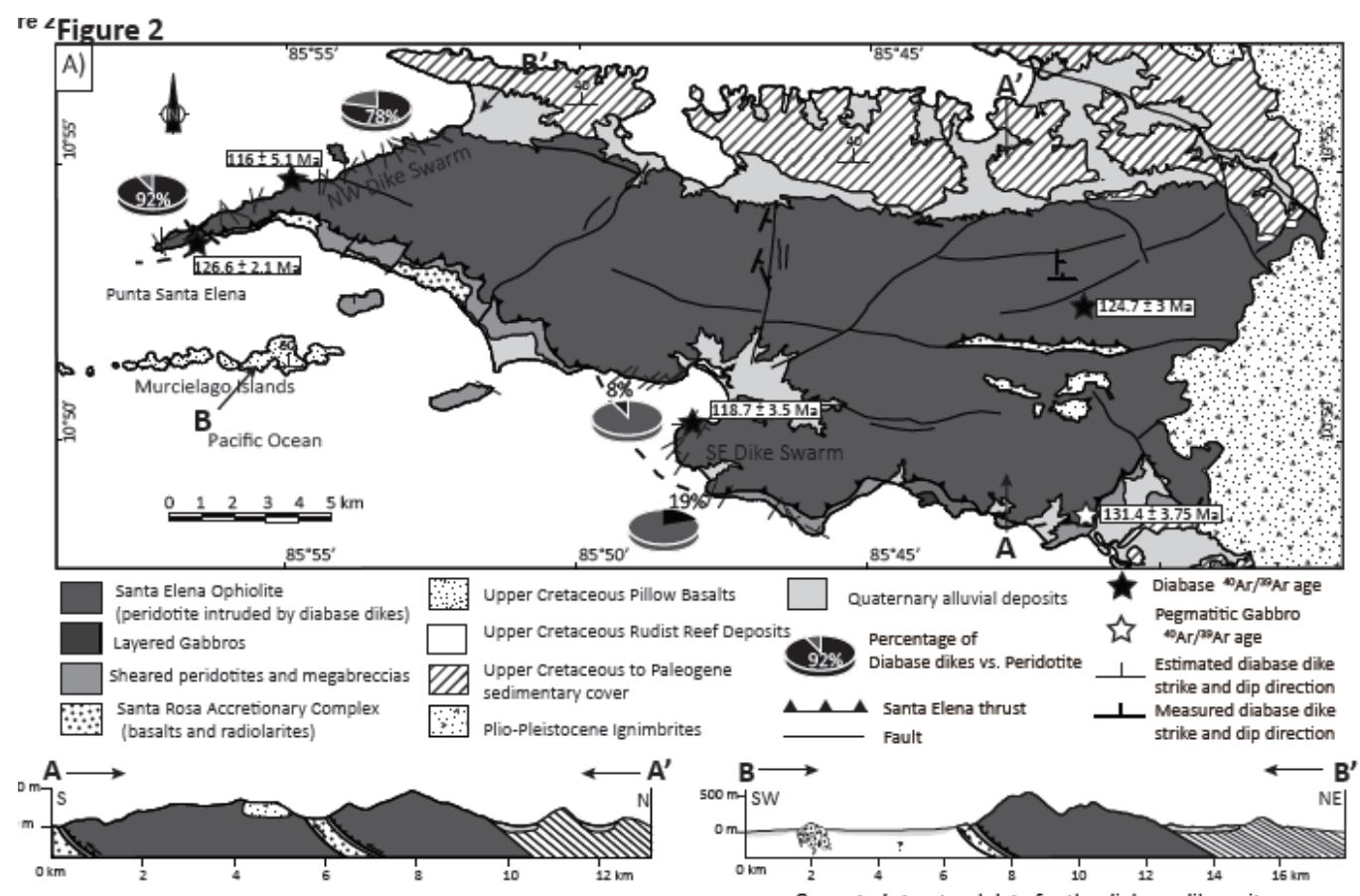

Corrected structural data for the diabase dike unit
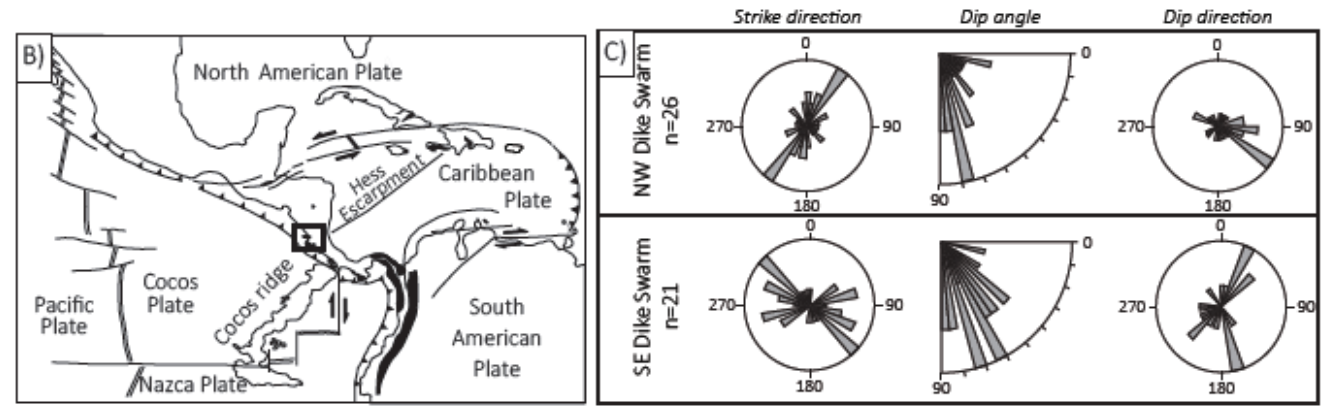
Figure 3
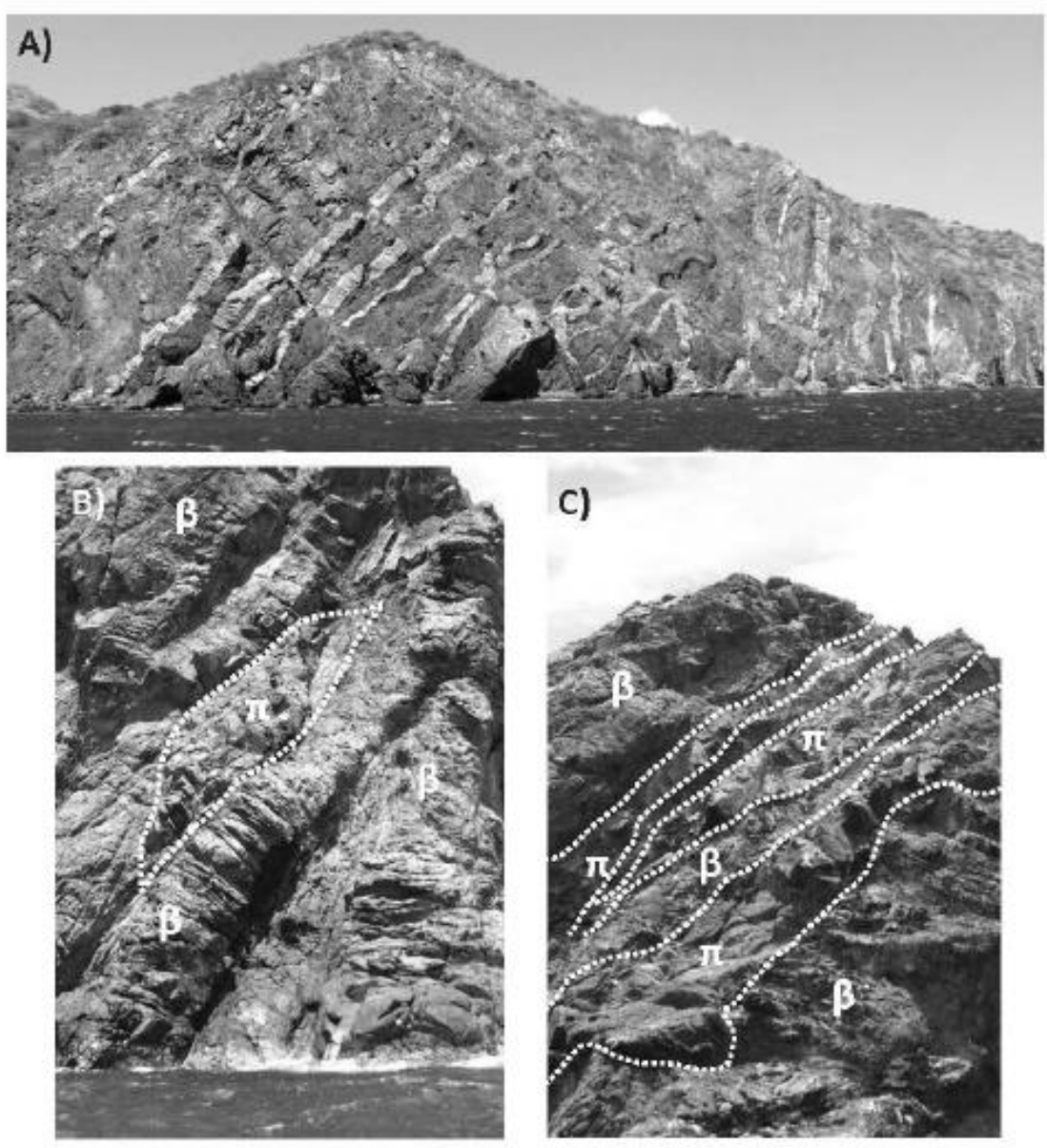

C)
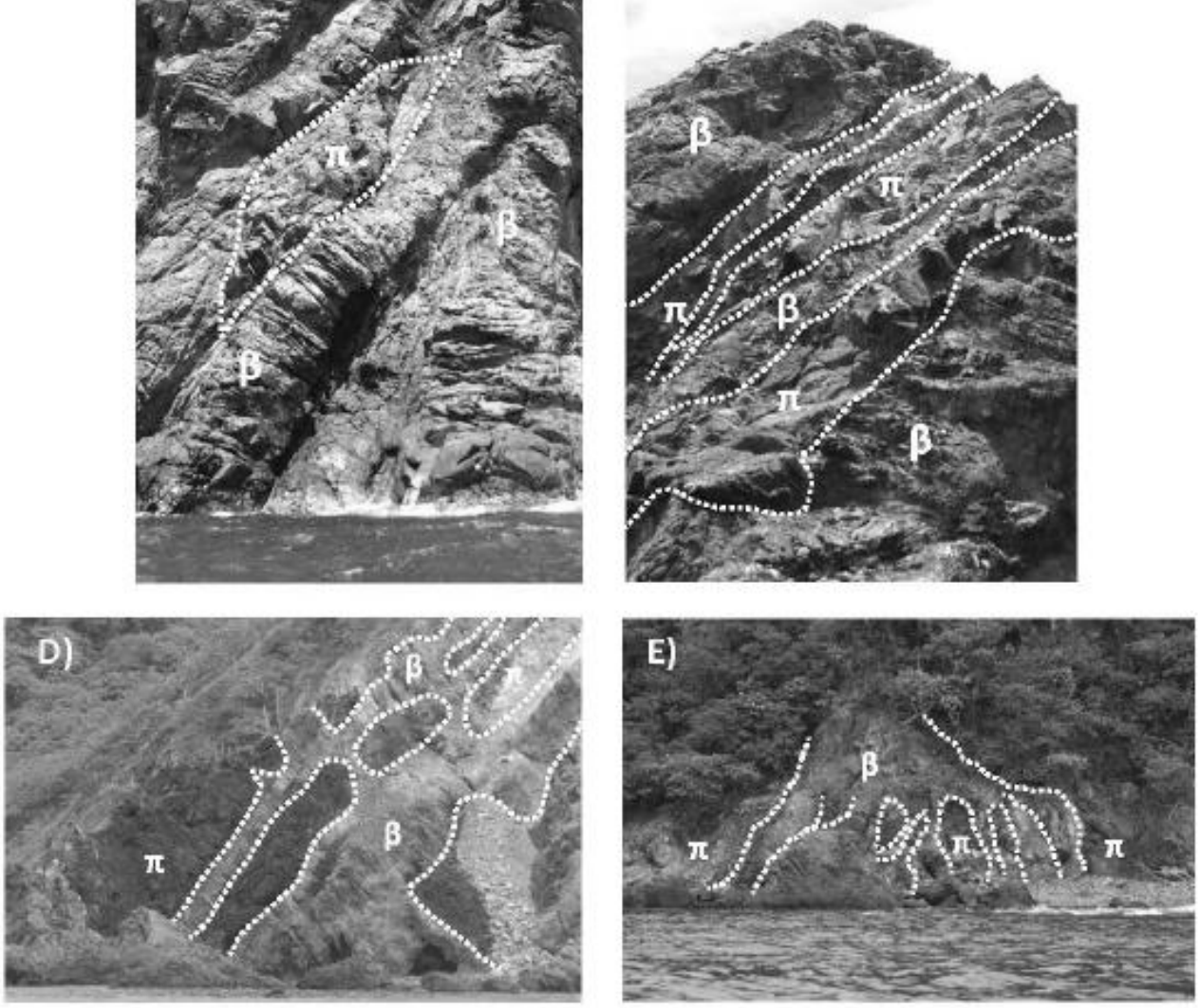


\section{Figure 4}

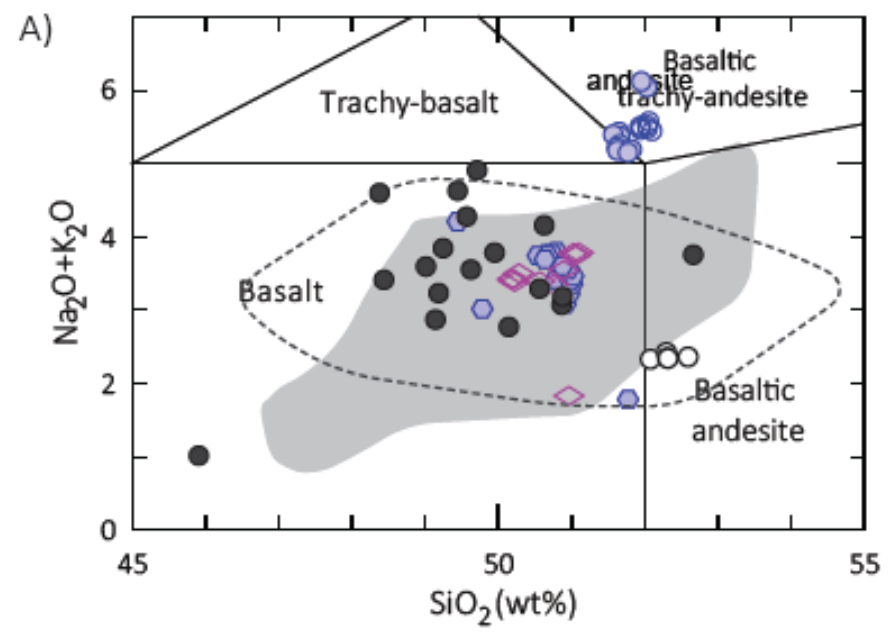

B)

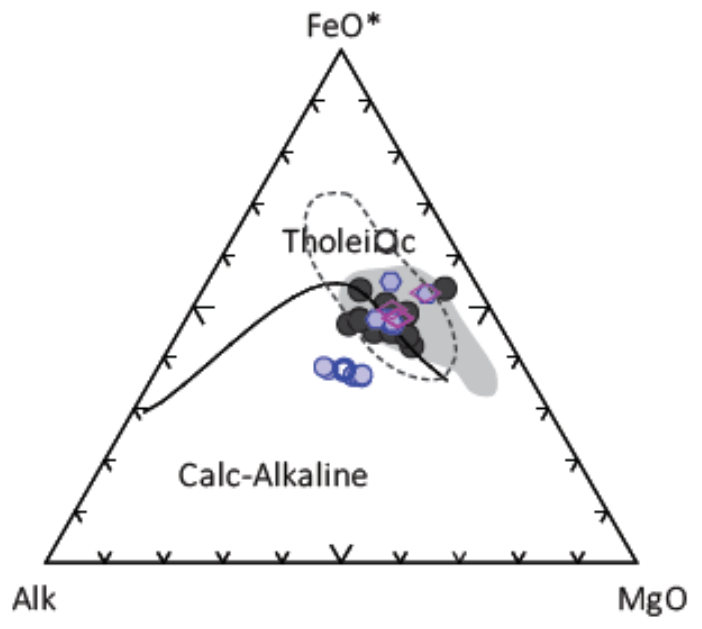

Santa Elena Diabase Dikes

- Murcielago Islands basaltic glasses

Analyses from Literature

MORB data from Gale et al. (2013) 
Figure 5
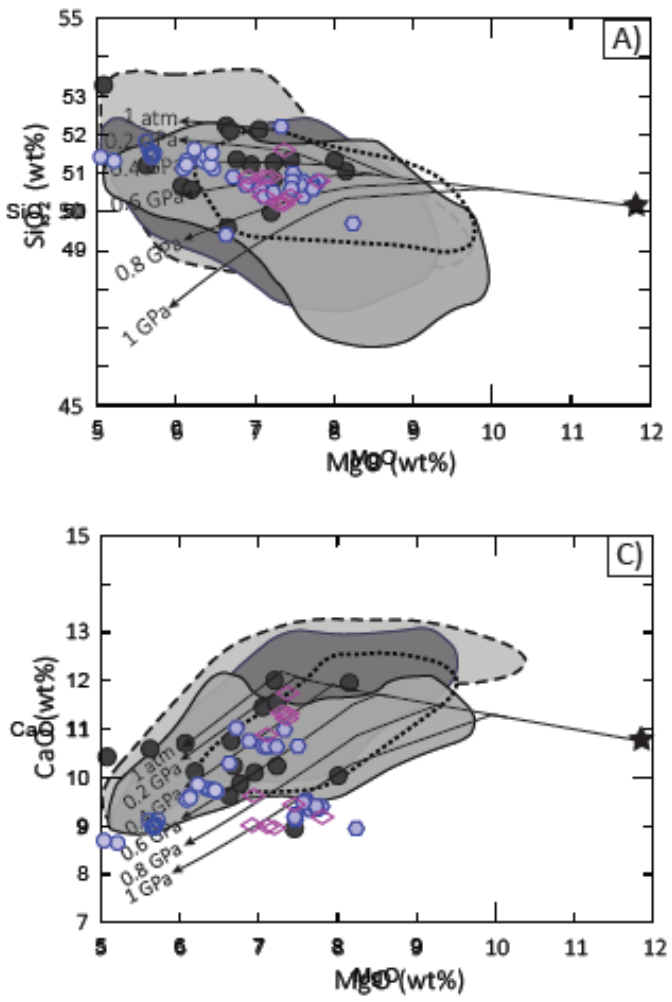

- Santa Elena Diabase Dikes

Primary Magma

Global Mid-Ocean Ridge data (Gale et al., 2013)

Fast spreading oceanic ridges (EPR)

Slow spreading oceanic ridges (MARR)

Ultra-slow spreading oceanic ridges (SWIR, GAK)

Back-arc basins (BMRN, LAU, SCO)
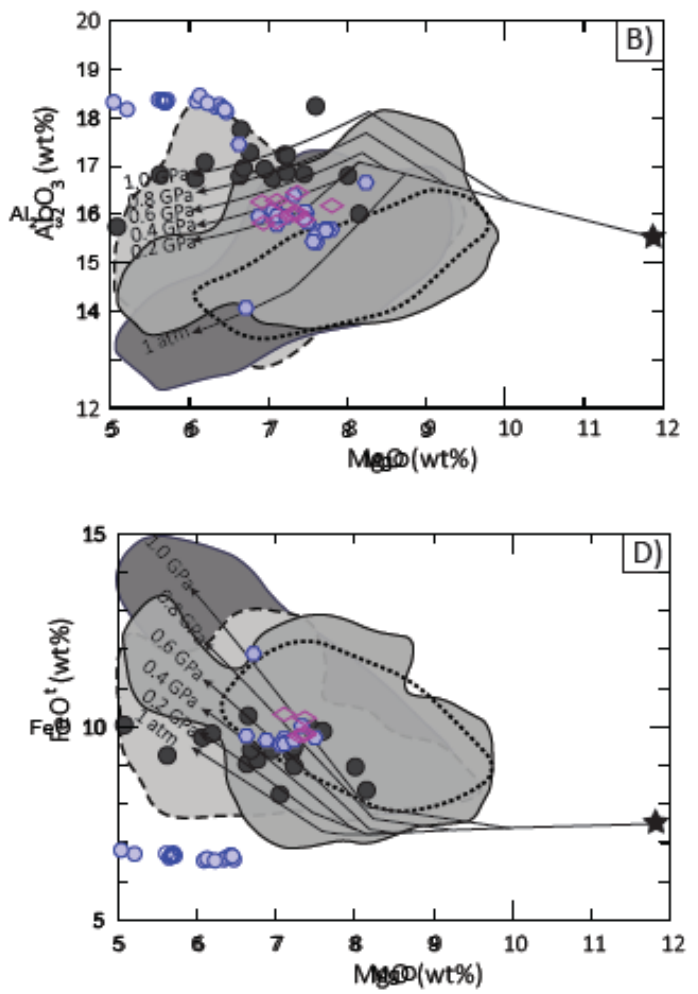

E)

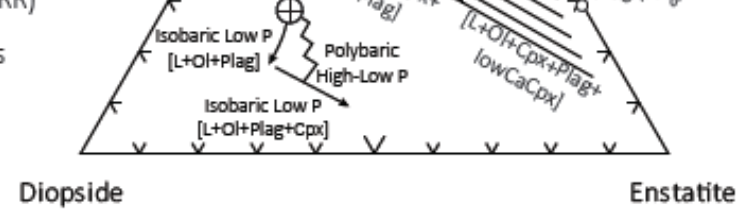


Figure 6
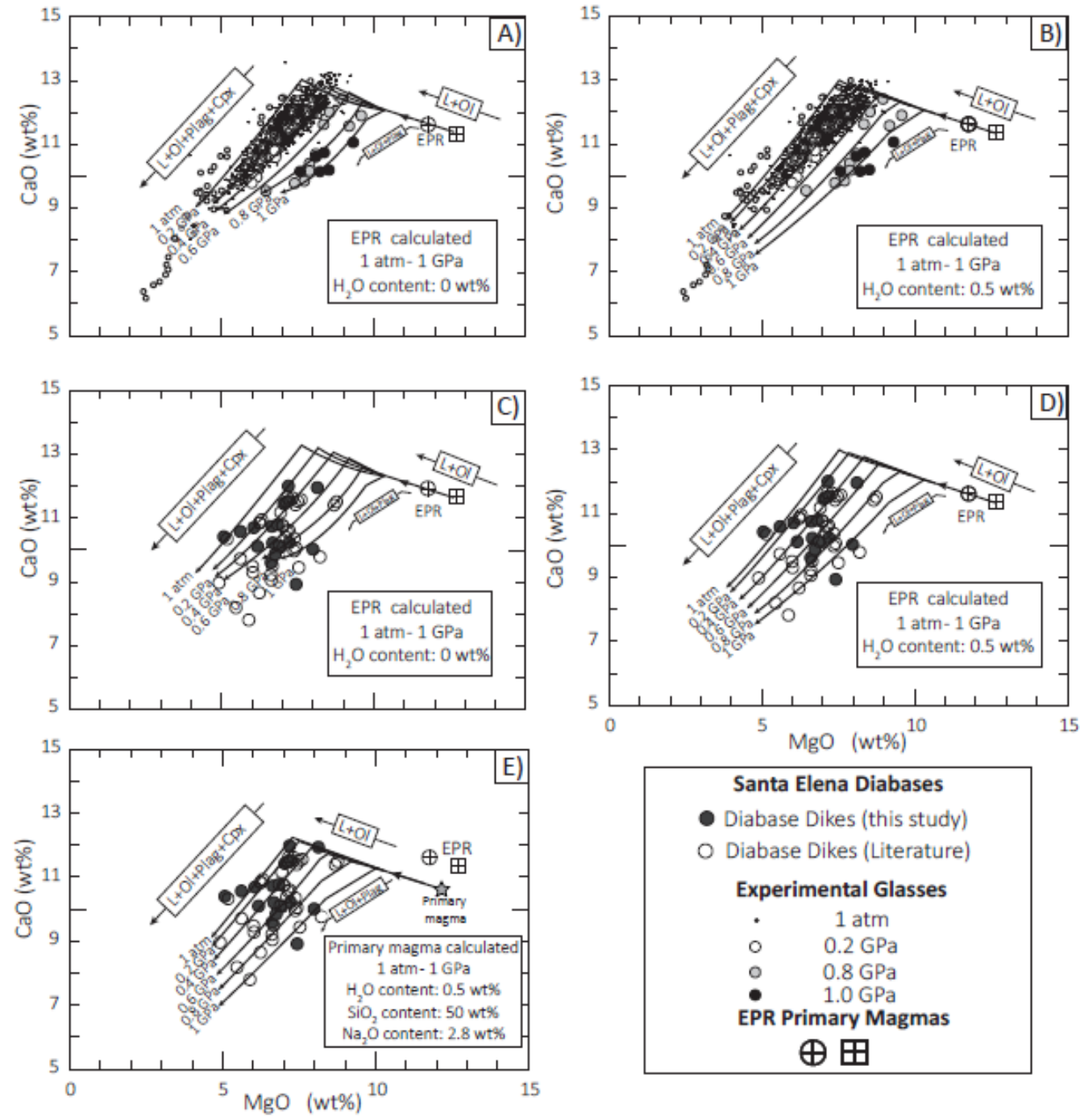

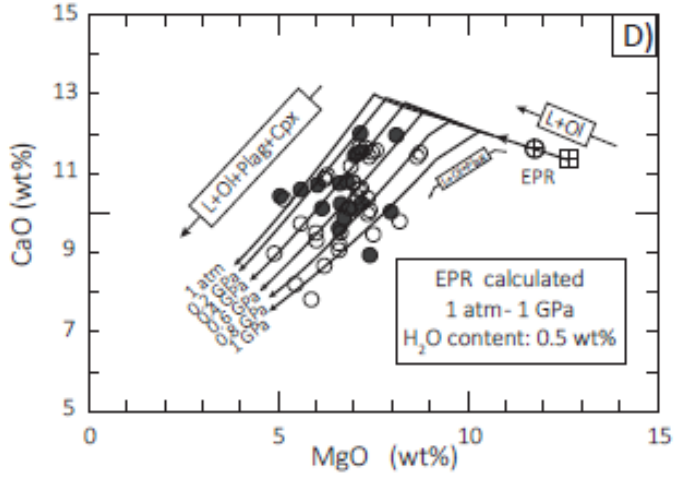

Santa Elena Diabases

- Diabase Dikes (this study)

Experimental Glasses

- $1 \mathrm{~atm}$

○ $\quad 0.2 \mathrm{GPa}$

$\circ \quad 0.8 \mathrm{GPa}$

EPR Primary Magmas

$\oplus$ 田
- Diabase Dikes (Literature) 
Figure 7
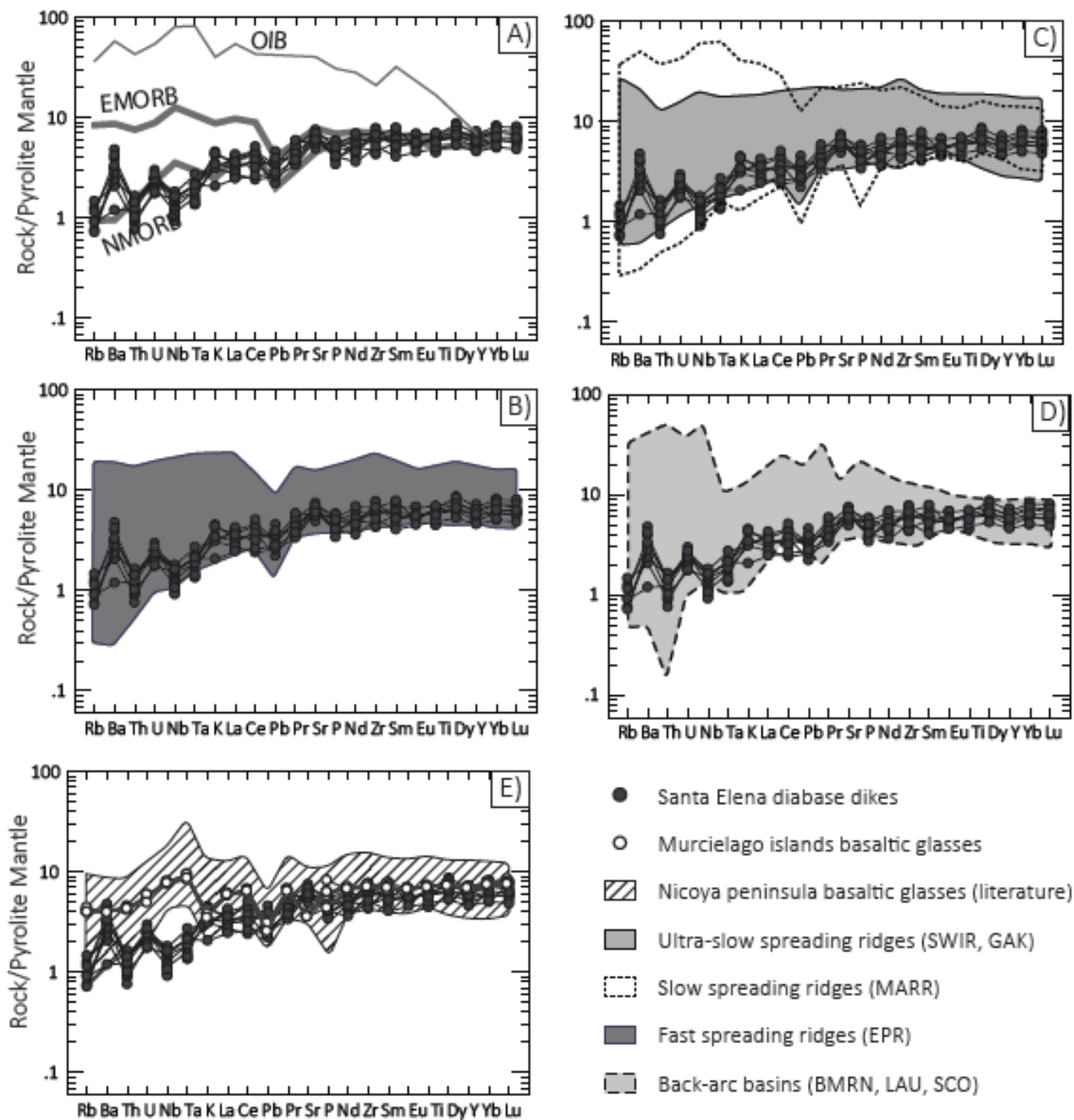

- Santa Elena diabase dikes

- Murcielago islands basaltic glasses

$\square$ Nicoya peninsula basaltic glasses (literature)

Ultra-slow spreading ridges (SWIR, GAK)

Slow spreading ridges (MARR)

Fast spreading ridges (EPR)

I- B Back-arc basins (BMRN, LAU, SCO) 
Figure 8
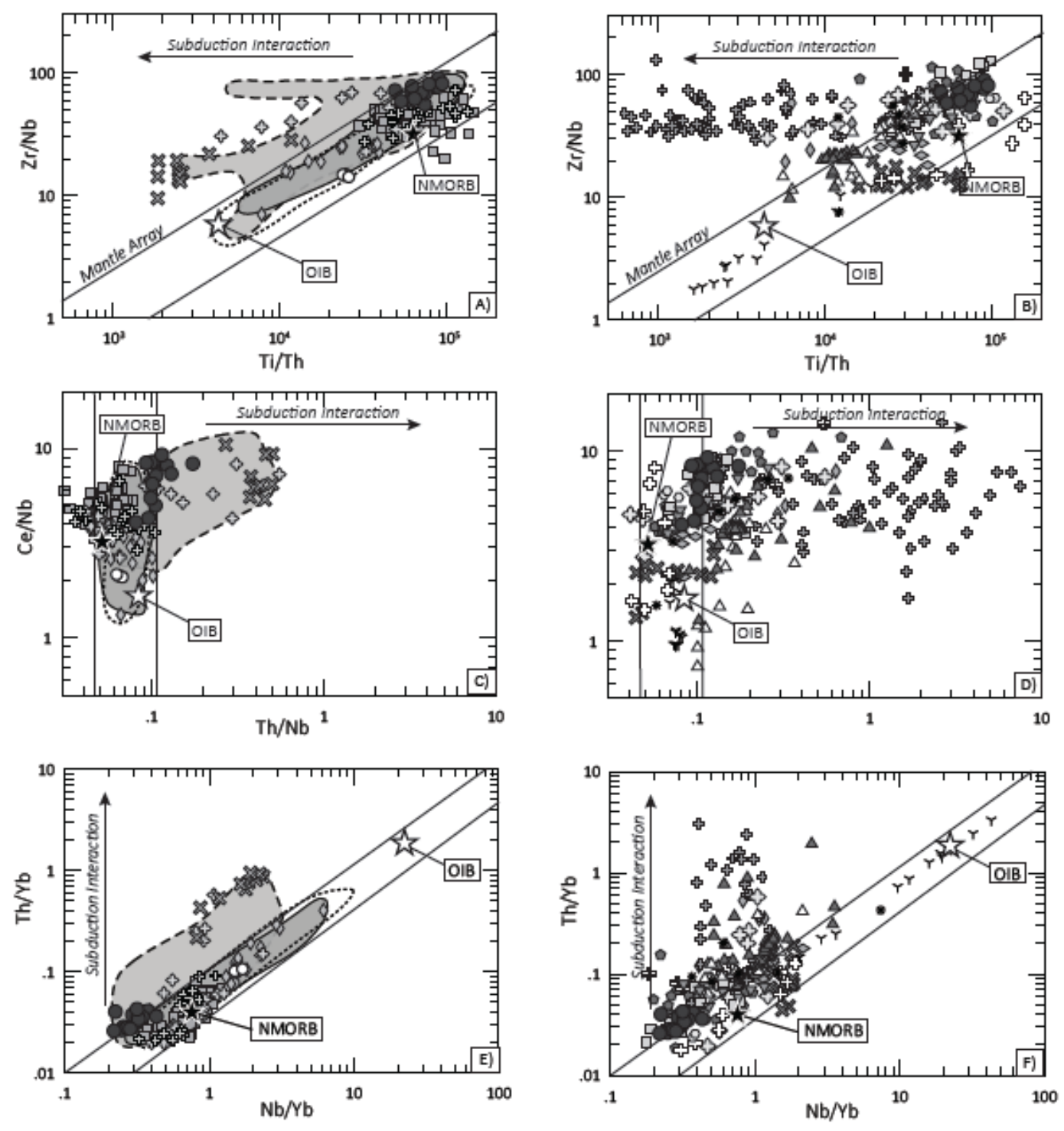

Other tectonic environments

\& Atlantis Massif, Mid-Atlantic ridge

口 Atlantis Bank, South West Indian Ridge

$\diamond$ San Souci Volcanic Formation, Trinidad

\& Atlantic oceanic crust (ca. $120 \mathrm{Ma}$ )

* Aves Ridge, Lesser Antilles

Slow spreading ridges (MARR)

$\square$ Ultra-slow spreading ridges (SWIR, GAK)

$\mathrm{I}_{-}^{-} \cdot-$ Back-arc spreading centers (BMRN, LAU, SCO)

Magmas within Ophiolites
Santa Elena
* Ingalls
क Duarte
O Murcielago Islands $\mathbf{\nabla}$ Tangihua $\quad$ * Loma La Monja
† Oman
- Shuanggou \& La Desiderade
$\checkmark$ Newfoundland
$\Delta$ Kizildag $Y$ Macquarie Island
\& Josephine
$\Delta$ Anatolia
+ Troodos
$\checkmark$ Mirdita
- Mayari-Baracoa 
Figure 9
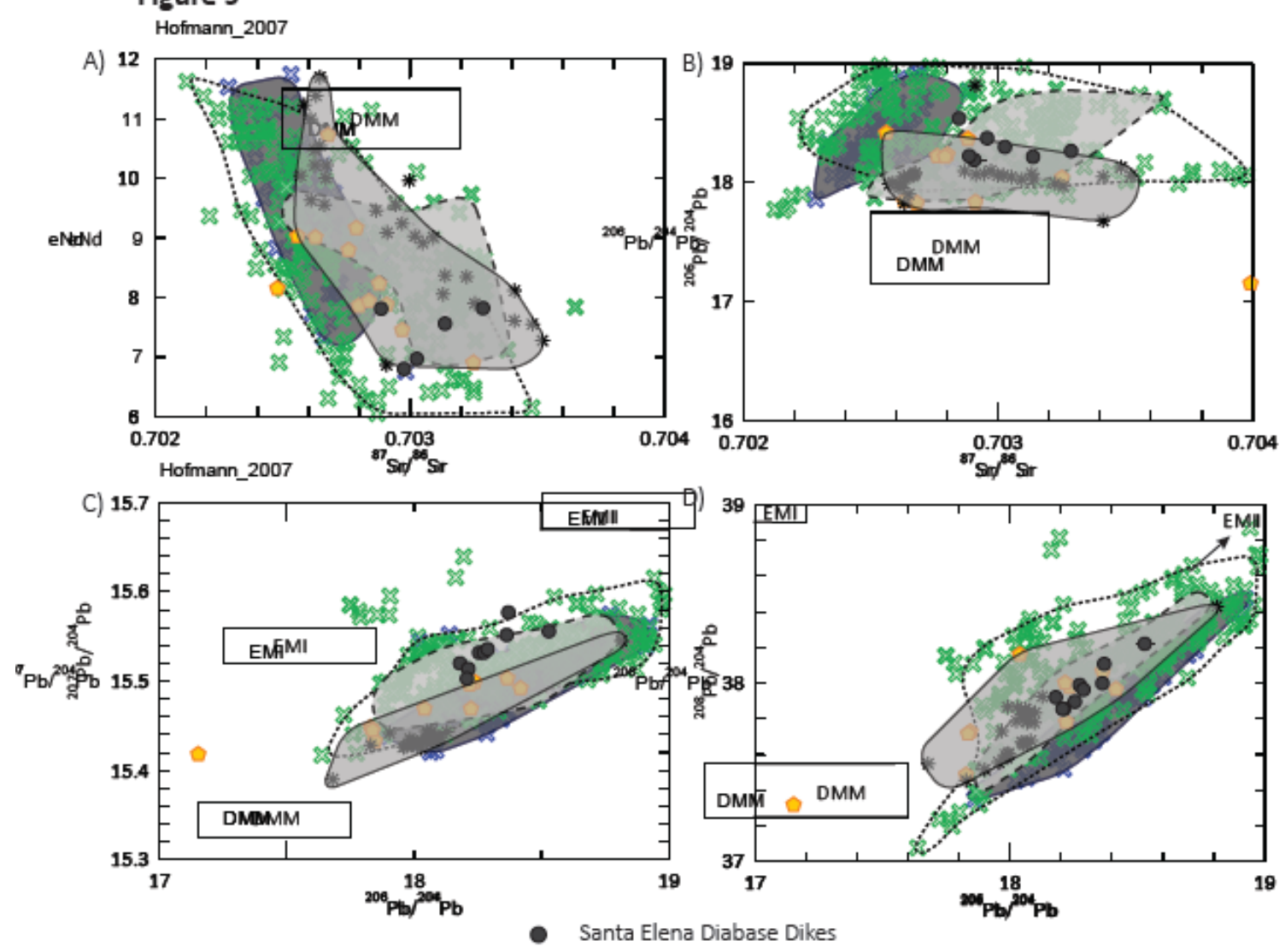

Global Mid-Ocean Ridge data (Gale et al., 2013)

$\square$ Fast spreading oceanic ridges (EPR) $\square$ Ultra-slow spreading oceanic ridges

(SWIR, GAK)

Slow spreading ridges (MARR) 
Figure 10

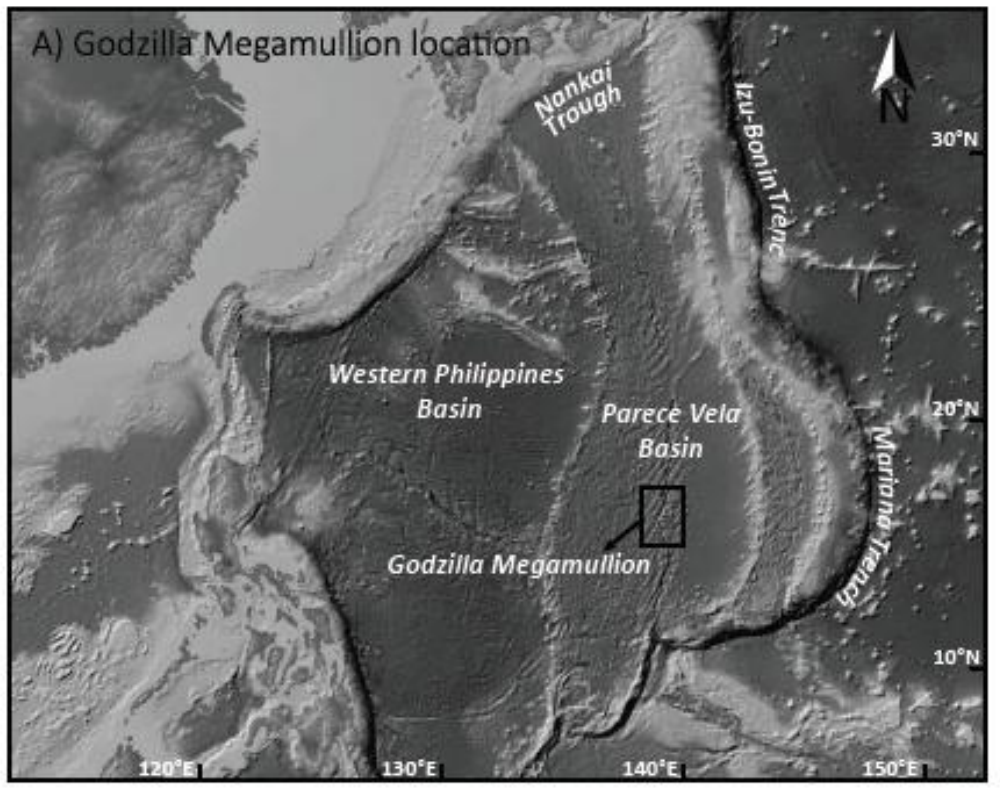

B) Oceanic Core Complex

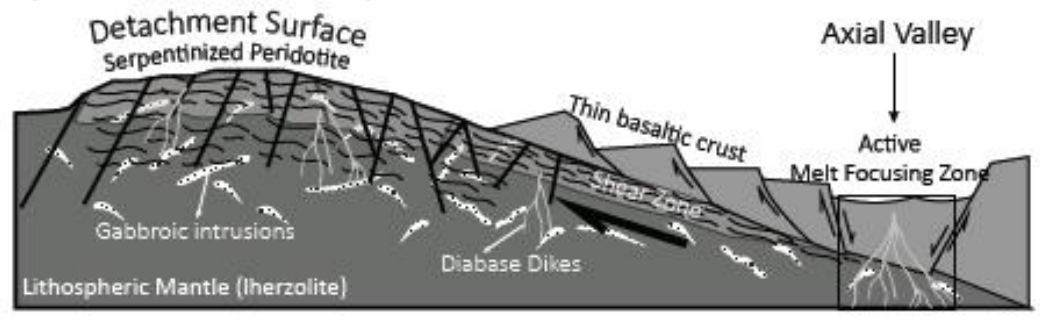

C) Santa Elena Ophiolite

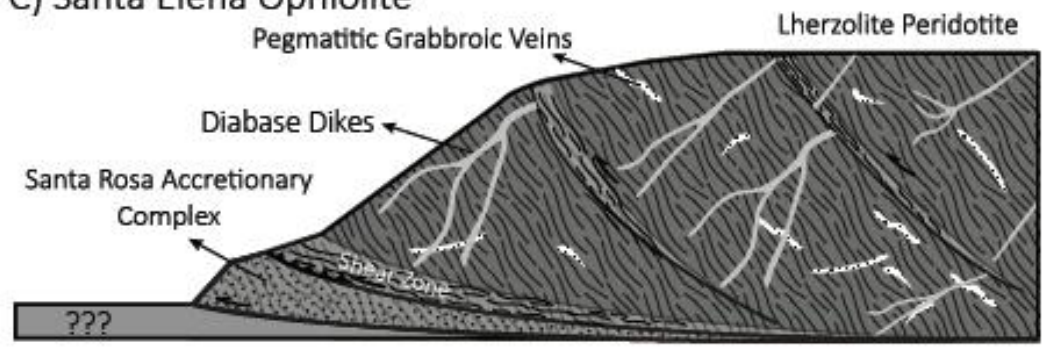




\section{Highlights}

- $\quad$ Santa Elena Ophiolite is a preserved melt-focusing zone of the lithospheric mantle.

- Its architecture \& geochemistry are similar to a slow/ultra-slow spreading system.

- It represents a fossil-fragment of an oceanic core complex from a back-arc basin. 